\title{
Analisis Risiko Return IHSG dan Return Dollar Terhadap Return Saham Sektoral Di Bursa Efek Indonesia (BEI)
}

\author{
Oleh \\ Eunike Elisabet, M.M \\ Ir. Tarsicius Sunaryo, MA., Ph.D
}

\section{PENDAHULUAN}

\section{I.I. Latar Belakang Masalah}

Pertumbuhan investasi di suatu negara akan dipengaruhi oleh pertumbuhan ekonomi negara tersebut. Semakin baik tingkat perekonomian suatu negara, maka semakin baik pula tingkat kemakmuran penduduknya. Tingkat kemakmuran yang lebih tinggi ini umumnya ditandai dengan adanya kenaikan tingkat pendapatan masyarakatnya. Dengan adanya peningkatan pendapatan tersebut, maka akan semakin banyak orang yang memiliki kelebihan dana, kelebihan dana tersebut dapat dimanfaatkan untuk disimpan dalam bentuk tabungan atau diinvestasikan dalam bentuk surat-surat berharga yang diperdagangkan dalam pasar modal.

Pertumbuhan ekonomi merupakan hal yang tidak dapat dipisahkan dari kehidupan manusia. Seiring perkembangan zaman,tentu kebutuhan terhadap manusia bertambah oleh karena itu ekonomi secara terus-menerus mengalami pertumbuhan dan perubahan. Perubahan yang secara umum terjadi pada perekonomian yang dialami suatu negara seperti inflasi, pengangguran, kesempatan kerja, hasil produksi dan sebagainya.

Jika hal ini ditangani dengan tepat maka suatu negara akan mengalami keadaan ekonomi yang stabil sehingga mempengaruhi kesejahteraan kehidupan penduduk yang ada di negara tersebut. Dalam menunjang pertumbuhan ekonomi yang stabil banyak perusahaan dalam menjalankan aktivitasnya tidak terlepas dari tujuan yang telah ditetapkan sebelumnya, karena tujuan perusahaan merupakan hal yang penting dan merupakan sasaran yang harus dicapai. Setiap perusahaan memiliki tujuan untuk mencari laba (profit), kontuinitas usaha serta pertumbuhan usaha. Tujuan tersebut ingin dicapai dalam usaha untuk memenuhi kepentingan para pemegang saham.

Krisis keuangan yang pernah terjadi di Indonesia tahun 1998 dan juga di Amerika Serikat disambut dengan kepanikan pemerintah di Indonesia dan juga organisasi nirlaba yang menjalankan bursa. Kepanikan juga dirasakan oleh Bursa Efek Indonesia yang menutup bursa pada pertengahan periode dengan alasan yang tidak pernah diungkapkan sebelumnya. Bursa tidak transparan sementara Emiten diminta untuk transparan.

Krisis ekonomi yang dimulai tahun 1998 merupakan awal runtuhnya pilar-pilar perekonomian nasional Indonesia. Ini ditandai dengan turunnya kepercayaan masyarakat terhadap perbankan Indonesia dalam bentuk penarikan dana besar- besaran (rush) oleh deposan untuk kemudian disimpan di luar negeri (capital flight). Dampak lain dari menurunnya kepercayaan masyarakat berimbas sampai ke pasar modal. Harga-harga saham menurun secara tajam sehingga menimbulkan kerugian yang cukup signifikan bagi investor.

Seperti yang dikutib publikasi Krisis Ekonomi Global dan Dampaknya terhadap Perekonomian Indonesia Outlook Ekonomi Indonesia (2009), Sebelum Lehman 
Brothers mengumumkan kebangkrutannya, nilai tukar rupiah masih stabil di level Rp 9.000 per dolar AS. Pada pertengahan September 2008, setelah Lehman Brothers menyatakan diri bangkrut dan AIG di-bailout pemerintah Amerika, rupiah mulai berfluktuasi. Puncaknya, rupiah bergerak menembus angka Rp 12.650 per dolar AS pada 24 Nopember 2008. Meroketnya nilai tukar rupiah menembus angka psikologis (RpI0.000/ dolar) membuat panik perusahaan- perusahaan nasional yang masih mengandalkan bahan baku impor dan para pemilik modal yang tergerus nilai nominal dana mereka. Pusaran krisis global itu paling dekat menghajar bursa saham dan pasar keuangan. IHSG merupakan cerminan dari kegiatan pasar modal secara umum.

Peningkatan IHSG menunjukkan kondisi pasar modal sedang bullish (bergairah), sebaliknya jika menurun menunjukkan kondisi pasar modal sedang bearish (lesu). Untuk itu seorang investor harus memahami pola perilaku harga saham di pasar modal.

Untuk dapat berinvestasi dengan baik, investor harus memperhatikan informasi apa saja yang dapat mempengaruhi indeks harga saham di pasar modal.

Fluktuasi indeks harga saham dapat dipengaruhi oleh berbagai informasi yang terjadi di lapangan, kemudian informasi tersebut direspon oleh para pelaku pasar sebagai suatu sinyal yang dapat mempengaruhi para pelaku pasar dalam keputusan bertransaksi.

Pengambilan keputusan investasi dalam saham memerlukan pertimbangan, perhitungan dari analisis yang mendalam untuk menjamin keamanan dana yang diinvestasikan serta keuntungan yang diharapkan oleh investor. Calon investor harus mengenal dengan baik prospek dari perusahaan yang menjual surat berharganya. Selain itu para investor harus mengetahui potensi risiko pasar yang terjadi dalam pasar modal yang dihadapinya. Hal ini dapat diperoleh dengan mengidentifikasi informasi yang ada dan menganalisis risiko yang akan terjadi. Suatu informasi dikatakan relevan oleh investor jika informasi tersebut mampu mempengaruhi keputusan investor untuk melakukan transaksi di pasar modal, dan dari informasi tersebut investor dapat memprediksikan risiko atas keputusan yang telah diambil serta melakukan mitigasi atas risiko tersebut sehingga menghasilkan langkah pengambilan keputusan yang efisien dan akurat.
Investor berinvestasi di pasar modal sudah pasti mengharapkan tingkat keuntungan yang lebih. Dalam berinvestasi ada dua faktor yang harus dipertimbangkan oleh investor, yaitu tingkat pengembalian ( return ) dan tingkat risiko ( risk ). Dua faktor ini merupakan hal yang berlawanan, dalam hal ini investor menyukai tingkat pengembalian yang tinggi namun tidak menyukai risiko yang tinggi. Pada kenyataannya terdapat hubungan yang linear antara tingkat pengembalian ( return ) dan tingkat risiko ( risk ), karena semakin tinggi tingkat pengembalian yang diharapkan, maka semakin besar risiko yang akan dihadapi.

Ada beberapa sumber risiko yang dapat mempengaruhi besar kecilnya risiko suatu investasi, antara lain :risiko suku bunga, risiko pasar, risiko inflasi, risiko bisnis, risiko finansial, risiko likuiditas, dan risiko nilai tukar mata uang.

Di samping beberapa sumber risiko diatas, investor juga perlu memperhatikan adanya ketidakpastian di masa yang akan datang yang dapat menyebabkan munculnya dua jenis risiko, yaitu risiko sistematis ( systematic risk ) dan risiko tidak sistematis ( unsystematic risk ). Risiko sistematis biasanya di pengaruhi oleh keadaan pasar atau risiko ini akan dihadapi oleh semua aset yang listing di bursa. Sedangkan risiko tidak sistematis biasanya diakibatkan oleh kebijakan-kebijakan perusahaan dan hanya menimpa perusahaan yang bersangkutan.

Model keseimbangan merupakan salah satu cara untuk menentukan pengukur risiko yang relevan suatu aset, dan memahami bagaimana hubungan risiko dan tingkat pengembalian yang diharapkan untuk suatu aset dalam kondisi pasar yang seimbang. Salah satu model keseimbangan yang biasa digunakan adalah Capital Asset Pricing Model ( CAPM ). Tingkat pengembalian merupakan tujuan utama investor dalam berinvestasi. Capital Asset Pricing Model menjelaskan pentingnya untuk memaksimalkan tingkat pengembalian dengan tingkat risiko tertentu, dengan melakukan diversifikasi saham. Diversifikasi saham merupakan upaya melakukan investasi pada banyak saham sehingga risiko kerugian pada satu saham dapat di tutup dari keuntungan saham yang lainnya.

Semakin banyaknya perusahaan yang menjadi emiten di pasar modal, akan memunculkan berbagai 
macam kombinasi saham yang bisa di pilih oleh investor. Dalam menjalankan investasi, investor memilih untuk membeli saham perusahaan yang go public. Saham go public menjanjikan tingkat pengembalian yang tinggi tetapi juga memiliki resiko yang tinggi karena sifat komoditinya yang sangat peka terhadap perubahan baik di bidang politik, ekonomi dan moneter.

Isu yang menarik dari penelitian ini adalah OECD (Organisasi untuk Kerjasama dan Pembangunan Ekonomi ) memprediksi pertumbuhan ekonomi Indonesia pada tahun 2012 hingga 2016 rata-rata mencapai 6.6\% per tahun, atau tertinggi dibanding negara-negara ASEAN lainnya (sumber:VOA Indonesia). Namun laporan perekonomian Indonesia 2016 yang diterbitkan Bank Sentra Republik menunjukan adanya perlambatan pertumbuhan pendapatan sektoral riil, perlambatan pertumbuhan pendapatan ini menarik dicermati seiiring dengan pergerakan kurs dollar yang dalam periode 2012 s/d 2016 mengalami grafik trend kenaikan yang cukup fenomenal.

Terdapat banyak faktor yang perlu diperhatikan dalam berinvestasi terutama dalam permasalahan yang menjadi isu dari penelitian ini, karena dari faktor-faktor tersebut para investor bisa mengambil langkah yang tepat dalam melakukan investasinya di dunia pasar modal.

Berdasarkan bahasan masalah diatas penulis tertarik ingin membahas masalah index harga saham gabungan dengan judul" Analisis Risiko Return IHSG dan Return Dollar terhadap Return Saham Sektoral di BEI pada periode tahun 2012 - 2016."

\section{I.2. Identifikasi Masalah}

Berdasarkan latar belakang di atas, maka identifikasi masalah dalam penelitian ini adalah sebagai berikut: I. Apakah ada pengaruh risiko return IHSG terhadap return saham sektoral di BEI pada periode Tahun 2012 - 2016?

2. Apakah ada pengaruh risiko perekonomian Indonesia terhadap return saham sektoral di BEI pada periode 2012 - 2016?

3. Apakah ada pengaruh risiko return kurs dollar terhadap return saham sektoral di BEI pada periode 2012 - 2016?

4. Apakah ada pengaruh risiko kebijakan tingkat suku bunga terhadap return saham sektoral di BEl pada periode 2012 - 2016?

5. Apakah ada pengaruh risiko inflasi terhadap return saham sekotral di BEl pada periode 2012 2016?

\section{I.3. Pembatasan Masalah}

Adapun ruang lingkup pembahasan dalam penelitian ini dibatasi pada hal sebagai berikut :

I. Pengaruh risiko return IHSG terhadap return saham sektoral di BEl pada periode $2012 \mathrm{~s} / \mathrm{d} 2016$.

2. Pengaruh risiko return dollar terhadap return saham sektoral di BEl pada periode $2012 \mathrm{~s} / \mathrm{d} 2016$.

3. Pengaruh risiko antara return IHSG dan return kurs dollar terhadap return saham sektoral di BEI pada periode $2012 \mathrm{~s} / \mathrm{d} 2016$.

\section{I.4. Rumusan Masalah}

Berdasarkan identifikasi dan pembatasan masalah diatas, maka rumusan masalah dalam penelitian ini adalah sebagai berikut :

I. Bagaimana pengaruh risiko return IHSG terhadap return saham sektoral di BEl pada periode 2012 s/d 2016?

2. Bagaimana pengaruh risiko return kurs dollar terhadap return saham sektoral di BEI pada periode $2012 \mathrm{~s} / \mathrm{d} 2016$ ?

3. Bagaimana pengaruh risiko antara return IHSG dan return kurs dollar terhadap return saham sektoral di BEl pada periode 2012 s/d 2016?

\section{I.5. Tujuan Penelitian}

Adapun tujuan penelitian yang hendak dicapai dari pokok permasalahan yang telah dirumuskan di atas adalah:

I. Untuk mengetahui pengaruh risiko return IHSG terhadap return saham sektoral di BEI pada periode $2012 \mathrm{~s} / \mathrm{d} 2016$.

2. Untuk mengetahui pengaruh risiko return kurs dollar terhadap return saham sektoral di BEl pada periode $2012 \mathrm{~s} / \mathrm{d} 2016$.

3. Untuk mengetahui pengaruh risiko return IHSG 
dan return kurs dollar terhadap return saham sektoral di BEl pada periode 2012 s/d 2016.

\section{I.6. Manfaat Penelitian}

Adapun manfaat dari penelitian ini adalah sebagai berikut :

\section{Bagi investor}

Bagi investor dan emiten yang tercatat di BEl, hasil dari penelitian ini dapat membantu mereka dalam menentukan apakah akan menjual, membeli, ataukah menahan saham yang mereka miliki berkenaan dengan fluktuasi IHSG dan perubahan kurs dollar terhadap rupiah di BEl. Karena kesalahan dalam menentukan dan menerapkan strategi perdagangan di pasar modal, akan berakibat buruk bagi perusahaan atau investor sehingga dapat mengalami kerugian apabila retun saham IHSG dan pergerakan kurs dollar memang benar-benar berpengaruh terhadap saham saham sektoral.

\section{Bagi Peneliti Lainnya}

Penelitian ini diharapkan dapat memberikan manfaat pengembangan ilmu pengetahuan khususnya dalam bidang manajemen risiko keuangan serta dapat menjadi bahan referensi selanjutnya.

\section{TINJAUAN PUSTAKA}

\section{I. Landasan Teori}

\section{I.I.Pengertian Risiko}

Risiko merupakan suatu keadaan adanya ketidakpastian dan tingkat ketidakpastiannya terukur secara kuantitatif. Risiko dapat dikategorikan ke dalam risiko murni dan risiko spekulatif. Risiko murni merupakan risiko yang dapat mengakibatkan kerugian pada perusahaan, tapi tidak ada kemungkinan menguntungkan. Pada perusahaan dalam mengahadapi suatu risiko, misalnya kekayaan berupa mesin menanggung risiko murni, adanya kemungkinan mesin mengalami kerusakan, mulai dari kerusakan kecil sampai besar. Tetapi, tidak mungkin keadaan sebaliknya bisa terjadi, berupa kekayaan gedung yang menyebabkan kehancuran karena bencana alam, sedangkan risiko spekulatif adalah risiko yang dapat mengakibatkan dua kemungkinan, merugikan atau menguntungkan perusahaan, misalnya perusahaan yang menyimpan valuta asing seperti US\$ dan JPY dapat mengalami keuntungan dan kerugian. Simpanan tersebut menguntungkan bila nilai tukar mata uang tersebut menguat (Djohanputro, 2008).

Risiko merupakan bagian yang melekat pada setiap objek, baik objek tersebut dalam keadaan melakukan aktivitas maupun tidak melakukan aktivitas sama sekali. Menurut Redja (2008), tidak ada suatu definisi umum mengenai risiko, karena terdapat beberapa definisi tentang konsep risiko yang diinterpetasikan oleh berbagai profesi. The International Standard Organization (dalam ISO Guide 73:2009 Risk Management-Vocabulary) menjelaskan risiko sebagai dampak yang ditimbulkan dari ketidakpastian dalam upaya mencapai objektif.

Risiko sering ditandai dengan kejadian yang berpotensi muncul dan konsekuensi yang ditimbulkan , atau kombinasi dari keduanya. Risiko juga sering digambarkan sebagai kombinasi dari konsekuensi atas suatu kejadian (termasuk perubahan dalam suatu kondisi) dan kemungkinan yang berhubungan dengan suatu kejadian. Risiko dapat berdampak negatif terhadap tujuan perusahaan, dan lebih jauh dapat menimbulkan terjadinya kerugian atau ancaman bagi kelangsungan hidup perusahaan.

Dalam penelitian ini, peneliti menitik beratkan pada analisis risiko. Definisi risiko adalah Risk is the variability of return from those that are expected.

Menurut Sunaryo definisi risiko adalah kerugian karena kejadian yang tidak di harapkan muncul (Sunaryo, 2007:3).

Menurut The Internal Auditors (The Role of Internal Auditing in Enterprise - Wide Risk Management,2004) mendefinisikan risiko sebagai "Risk is the probability that an event or action, or inaction, may adversely effect the organization or activity under review."

Risiko adalah kemungkinan suatu peristiwa atau kejadian, atau akibat yang mungkin memberikan dampak terhadap organisasi atau aktivitas yang direview. Dampak atas risiko tersebut senantiasa mengarah pada suatu kerugian atau hal - hal buruk yang tidak diinginkan oleh perusahaan, yang pada akhirnya dampak tersebut akan berimbas pada terganggunya pencapaian tujuan perusahaan. 
Salah satu tokoh menyebutkan bahwa risiko merupakan kemungkinan kerugian, ketidakpastian, penyimpangan kenyataan dari hasil yang diharapkan dan probabilitas bahwa suatu hasil berbeda dari yang diharapkan. Dengan demikian risiko sebisa mungkin dihindari sedini mungkin, meskipun risiko yang terjadi mungkin disebabkan oleh aktivitas pencapaian tujuan perusahaan (Vaughan (1996).

Risiko didefinisikan sebagai "chance of bad outcome" atau suatu kemungkinan akan terjadinya hasil yang tidak diinginkan yang dapat menimbulkan kerugian apabila tidak diantisipasi serta dikelola dengan baik (Work Book Level I Global Association of Risk Professionals, Badan Sertifikasi Manajemen Risiko, 2005:A4).

Dari penjelasan beberapa tokoh diatas dapat didefinisikan sebagai suatu keadaan yang dihadapi oleh organisasi dengan kemungkinan yang merugikan. Sehingga dapat dikatakan bahwa selama perusahaan mengalami kerugian walau sekecil apapun, hal tersebut dianggap resiko.

\section{I.2. Risiko Investasi di Pasar Modal}

Menurut Marsis ( $2013: 30$ ), strategi dasar investor yang akan meningkatkan kinerja atau nilai portofolio investasi menjadi lebih baik adalah mengukur risiko dengan membandingkannya terhadap tingkat keuntungan yang diperoleh. Hal ini disebabkan adanya suatu ketidakpastian yang dapat dianggap sebagai risiko investasi. Adapun risiko-risiko yang mungkin dihadapi oleh investor, antara lain :

\section{Risiko daya beli}

Risiko ini berkaitan dengan kemungkinan investor menerima keuntungan yang daya belinya jauh lebih kecil dibandingkan keuntungan yang diperoleh semula, akibat terjadinya inflasi yang menyebabkan nilai riil pendapatan akan lebih kecil. Risiko ini umumnya merupakan dampak dari inflasi suatu investasi. Inflasi adalah kondisi dimana terjadi peningkatan harga tinggi yang menyebabkan daya beli konsumen menurun.

\section{Risiko bisnis}

Risiko ini berkaitan dengan menurunnya kemampuan memperoleh laba, yang pada gilirannya akan me- ngurangi kemampuan perusahaan (emiten) membayar bunga atau dividen.

\section{Risiko tingkat bunga}

Naiknya tingkat bunga biasanya menekan harga jenis-jenis surat berharga yang berpendapatan tetap termasuk harga saham. Biasanya kenaikan tingkat bunga berjalan tidak searah dengan harga-harga instrumen pasar modal. Dengan naiknya tingkat bunga, maka menurunkan harga-harga di pasar modal.

\section{Risiko pasar}

Apabila pasar bergairah (bullish) umumnya hampir semua harga saham di Bursa Efek mengalami kenaikan. Sebaliknya, apabila pasar lesu (bearish) harga sahamsaham akan ikut pula mengalami penurunan. Hal ini dapat menyebabkan harga-harga surat berharga anjlok.

\section{Risiko likuiditas}

Risiko ini berkaitan dengan kemampuan suatu surat berharga untuk dapat segera diperjualbelikan tanpa mengalami kerugian.

\section{I.3. Investasi Dalam Bentuk Saham}

Investasi merupakan penempatan sejumlah dana pada saat ini dengan harapan untuk memperoleh keuntungan di masa mendatang, Halim (2003). Investasi dalam bentuk saham yang dikelompokkan sebagai investasi jangka panjang biasanya dilakukan dengan berbagai tujuan, Jones (2000) yaitu untuk mengawasi perusahaan itu sendiri, memperoleh pendapatan yang tetap setiap periode, membentuk suatu dana khusus, menjamin kontinuitas suplai bahan dan menjaga hubungan antar anak perusahaan. Risk and Return Tandelilin (200I), mendefinisikan return sebagai imbalan atas keberanian investor menanggung risiko atas investasi yang dilakukan. Penjumlahan yield dan capital gain disebut sebagai return total suatu investasi. Risiko merupakan kemungkinan perbedaan antara return aktual yang diterima dengan return yang diharapakan. Risiko dari suatu portofolio saham bergantung kepada proporsi dari saham-saham individu, varians, dan covarians dari saham- saham tersebut. Perubahan yang terjadi pada variabel-variabel tersebut akan merubah risiko dari portofolio. 


\section{I.4. Indeks Saham Gabungan (IHSG)}

Untuk mengukur kinerja saham yang diperdagangkan di bursa digunakan suatu indeks, yaitu Indeks Harga Saham Gabungan (IHSG). IHSG merupakan angka indeks harga saham yang sudah disusun dan dihitung sehingga menghasilkan trend, dimana angka indeks adalah angka yang diolah sedemikian rupa sehingga dapat digunakan membandingkan kejadian yang dapat berupa perubahan harga saham dari waktu ke waktu. Dalam perhitungan angka indeks ini digunakan waktu dasar (base period) dan waktu yang sedang berjalan ( given/parent period), Jogiyanto (2003).

Indeks Harga Saham Gabungan (IHSG) menggambarkan suatu rangkaian informasi historis mengenai pergerakan harga saham gabungan seluruh saham, sampai pada tanggal tertentu. Pergerakan harga saham tersebut disajikan setiap hari, berdasarkan harga penutupan di bursa pada hari tersebut. Indeks tersebut disajikan untuk periode tertentu. Indeks harga saham gabungan berubah setiap hari karena,

\section{I.5. Indeks Saham Sektoral}

Indeks sektoral BEl adalah sub indeks dari IHSG. Semua saham yang tercatat di BEI di klasifikasikan ke dalam sembilan sektor menurut klasifikasi industri yang telah ditetapkan BEI, yang diberi nama JASICA (Jakarta Industrial Classification). Kesembilan sektor tersebut adalah:

A. Sektor-sektor Primer (Ekstraktif)

Sektor I : Pertanian

Sektor 2 : Pertambangan

B. Sektor-sektor Sekunder (Industri Pengolahan / Manufaktur)

Sektor 3 : Industri Dasar dan Kimia

Sektor 4 : Aneka Industri

Sektor 5 : Industri Barang Konsumsi

C. Sektor-sektor Tersier (Industri Jasa / Nonmanufaktur)

Sektor 6 : Properti dan Real Estate

Sektor 7 :Transportasi dan Infrastruktur

Sektor 8 : Keuangan

Sektor 9 : Perdagangan, Jasa dan Investasi

Selain sembilan sektor tersebut di atas, BEI juga menghitung Indeks Industri Manufaktur (Industri Pengolahan) yang merupakan gabungan dari saham- saham yang terklasifikasikan dalam sektor 3 , sektor 4 dan sektor 5 .

Indeks sektoral diperkenalkan pada tanggal 2 Januari 1996 dengan nilai awal indeks adalah 100 untuk setiap sektor dan menggunakan hari dasar tanggal 28 Desember 1995.

\subsubsection{Pengukuran Risiko dengan Pendekatan Pasar}

Total risiko portfolio terdiri dari dua komponen yaitu resiko sistematis (systematic risk / market risk I nondivesifiable risk) dan resiko tidak sistematis (unsystematic risk / company-specific risk /diversifiable risk).

Beta adalah menunjukan koefisien risiko sistematis. Berikut gambar yang menunjukan hubungan risiko total, risiko sistematis dan tidak sistematis pada portofolio :

\section{Hubungan resiko total, resiko sistematis dan tidak sistematis}

Risiko sistematis mempengaruhi semua sekuritas walaupun dalam tingkat yang berbeda. Risiko sistematis adalah resiko yang terjadi karena pengaruh pasar secara keseluruhan misalnya perubahan keadaan ekonomi secara umum, pengaruh kebijakan fiskal dan moneter, inflasi dan perubahan situasi pasar minyak. Risiko ini adalah bagian dari total risiko sekuritas yang tidak dapat dihilangkan dengan diversifikasi portofolio. Dengan telah dilakukan diversifikasi portofolio secara optimal maka risiko tersebut juga risiko pasar yang diukur dengan beta $(\beta)$.

Risiko tidak sistematis adalah risiko yang unik terdapat pada suatu perusahaan tertentu. Risiko tidak sistematis meliputi faktor-faktor spesifik pada suatu perusahaan misalnya pemogokan, ketinggalan teknologi, pengembangan produk baru dan kegiatan lain dalam perusahan tersebut. Risiko tidak sistematis adalah bagian dari total risiko sekuritas yang dapat dihilangkan dengan diversifikasi portofolio, disebut juga diversifiable risk. Oleh karena itu, risiko tidak sistematis harus diatasi dengan melakukan diversifikasi, investor tidak dapat mengharapkan adanya keuntungan tidak disengaja dari menangung risiko yang dapat dihindari ini, sedangkan dalam risiko sistematis, investor dapat mengharapkan keuntungan tidak disengaja dari keadaan perekonomian yang 
membaik. Beta suatu saham sebagai risiko sistematis mempengaruhi tingkat return diisyaratkan (required rate of return) saham tersebut. Hubungan beta saham dengan tingkat return diisyaratkan saham dengan beberapa pendekatan :

\subsection{Kerangka Pemikiran Teoritis}

Berdasarkan beberapa konsep dasar dan telaah pustaka diatas maka Kerangka Pemikiran Teoritis yang digunakan dalam penelitian ini dapat dilihat dalam Gambar 6. dibawah ini :

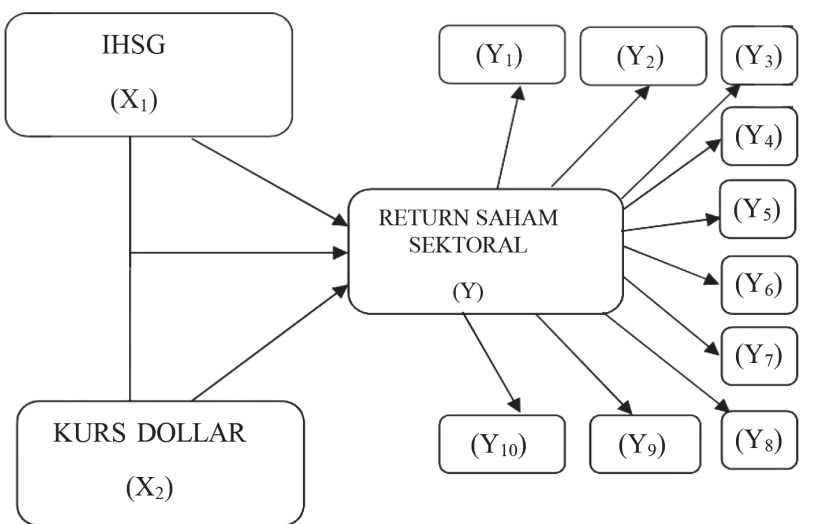

\section{Gambar 6. Kerangka Berpikir Teoritis}

Keterangan :

$X_{1} \quad=$ Return Indeks Harga Saham Gabungan

$\mathrm{X}_{2}=$ Return Kurs Dollar

$Y_{1} \quad=$ Return Saham Pertanian

$Y_{2} \quad=$ Return Saham Pertambangan

$\mathrm{Y}_{3} \quad=$ Return Saham Industri Pasar

$Y_{4} \quad=$ Return Saham Aneka Industri

$\mathrm{Y}_{5} \quad=$ Return Saham Konsumsi

$Y_{6} \quad=$ Return Saham Property

$\mathrm{Y}_{7} \quad=$ Return Saham Infrastruktur

$\mathrm{Y}_{8} \quad=$ Return Saham Keuangan

$Y_{9} \quad=$ Return Saham Perdagangan

$Y_{10}=$ Return Saham Manufaktur

\subsection{Hipotesis}

Berdasarkan model regresi yang telah dikemukakan diatas, maka dilakukan pembuatan uji hipotesis seperti berikut ini:
I. Risiko Pengaruh Return IHSG dengan Return Saham Sektoral

H0: Tidak ada risiko pengaruh antara Return IHSG dengan Return Saham Sektoral

$\mathrm{HI}$ : Ada risiko pengaruh antara Return IHSG dengan Return Saham Sektoral

2. Risiko Pengaruh Return Kurs Dollar dengan Return Saham Sektoral

H0: Tidak ada risiko pengaruh antara Return Kurs Dollar dengan Return Saham Sektoral

$\mathrm{HI}$ : Ada risiko pengaruh antara Return Kurs Dollar engan Return Saham Sektoral

3. Risiko Pengaruh Return IHSG dan Return Kurs Dollar dengan Return Saham Sektoral

H0: Tidak ada risiko pengaruh antara Return IHSG dan Return Kurs Dollar dengan Return Saham Sektoral

$\mathrm{HI}$ : Ada risiko pengaruh antara Return IHSG dan Return Kurs Dollar dengan Return Saham Sektoral

\section{METODE PENELITIAN}

\section{I. Variabel Penelitian dan Definisi Operasional}

\section{I.I. Variabel Penelitian}

Variabel-variabel yang digunakan dalam penelitian ini adalah variabel dependen dan variabel independen. Variabel dependen (terikat) adalah variabel yang dipengaruhi atau yang menjadi akibat karena adanya variabel bebas. Sedangkan variabel independen (bebas) adalah variabel yang mempengaruhi atau yang menjadi sebab perubahannya atau timbulnya variabel dependen (Soegiyono,2003). Variabel terikat yang digunakan dalam penelitian ini adalah Indeks Saham Sektoral sedangkan variabel bebasnya adalah Return IHSG dan Return Kurs Dollar.

\section{I.2. Definisi Operasional Variabel}

Penelitian ini menggunakan satu variabel dependen dan empat variabel independen. Definisi operasional masing-masing variabel dalam penelitian ini sebagai berikut:
I)
Indeks Harga Saham Gabungan (IHSG)
Indeks Harga saham Gabungan (IHSG) adalah 
indeks harga yang merupakan gabungan harga semua saham yang tercatat di Bursa Efek Indonesia (BEI), pengukuran yang dilakukan adalah dalam satuan poin.

\section{2) Kurs dollar Amerika}

Nilai tukar adalah harga mata uang suatu negara terhadap mata uang negara lain. Nilai tukar yang digunakan adalah kurs dolar Amerika terhadap rupiah yang dihitung berdasarkan kurs tengah yang dihitung berdasarkan kurs jual dan kurs beli diatur oleh Bank Indonesia.

\section{3) Indeks Saham Sektoral}

Indeks harga saham sektoral adalah indeks harga saham yang menggunakan semua saham dalam suatu sektor. Di BEl, ada sembilan indeks harga saham sektoral yaitu: pertanian, pertambangan, industri dasar, aneka industri, konsumsi, properti, infrastruktur, keuangan, perdagangan dan jasa, dan manufaktur.

\subsection{Jenis dan Sumber Data}

Menurut Kuncoro (200I), data diperoleh dengan mengukur nilai satu atau lebih variabel dalam sampel (populasi), semua data yang ada gilirannnya merupakan variabel yang kita ukur, dapat diklasifikasikan menjadi data kuantitatif dan data kualitatif. Jenis data yang digunakan dalam penelitian ini adalah data kuantitatif, yaitu data yang diukur dalam suatu skala numerik (angka). Data kuatitatif disini berupa data runtut waktu (time series) yaitu data yang disusun menurut waktu pada suatu variabel tertentu.

Penelitian ini menggunakan data sekunder yaitu data yang telah dikumpulkan oleh lembaga pengumpul data serta di publikasikan pada masyarakat pengguna data. Data dalam penelitian ini diperoleh dari hasil publikasi dari Bursa Efek Indonesia (BEI) meliputi data Indeks Saham Sektoral, Indeks Harga Saham Gabungan (IHSG), dan kurs dollar Amerika terhadap rupiah (US\$/ Rp) dengan menggunakan kurs tengah yang dihitung atas dasar kurs jual dan kurs beli yang ditetapkan Bank Indonesia, jumlah uang beredar yang berbentuk data bulanan periode $2012 \mathrm{~s} / \mathrm{d} 2016$.

\subsection{Metode Pengumpulan Data}

Dalam penelitian ini metode yang digunakan dalam pegumpulam data adalah metode dokumentasi, yaitu dengan mencatat dan mengcopy data-data tertulis yang berhubungan dengan masalah penelitian baik dari sumber dokumen/buku-buku, koran, majalah, internet dan lain lain mengenai kurs rupiah, Indeks Harga Saham Gabungan (IHSG) dan Indeks Saham Sektoral berupa data bulanan/tahunan periode $2012 \mathrm{~s} / \mathrm{d} 2016$.

\subsection{Analisis Data}

Dalam penelitian ini, teknik analisis data yang digunakan sebagai berikut:

I. Analisis deskriptif, dengan menggunakan tabel dan grafik.

2. Analisis kuantitatif, dilakukan dengan membuat persamaan regresi dengan Indeks Harga Saham Sektoral sebagai variabel tak bebas dan variabel ekonomi makro sebagai variabel bebas.

\subsection{Metode Analisis}

Metode anilisis data yang digunakan dalam penelitian ini adalah regresi. Menurut Tabachnick dan Fidell (1996: 128), hasil analisis regresi adalah berupa koefisien regresi untuk masing-masing variabel bebas (independen). Koefisien ini diperoleh dengan cara memprediksi nilai variabel tidak bebas (dependen) dengan suatu persamaan. Koefisien regresi dihitung dengan dua tujuan sekaligus, yaitu: pertama, meminimumkan penyimpangan antara nilai aktual dan nilai estimasi variabel dependen; kedua, mengoptimalkan korelasi antara nilai aktual dan nilai estimasi variabel dependen berdasarkan data yang ada (Mudrajad Kuncoro, 2001 : 92). Dengan menganggap $\mathbf{Y}_{(\mathbf{I - 1 0})}=\mathbf{f}\left(\mathbf{X}_{1}, \mathbf{X}_{\mathbf{2}}, \mathbf{X}_{\mathbf{3}}, \mathbf{X} \mathbf{4}\right)$ dalam hubungan fungsional di mana $Y$ adalah fungsi linear, maka model regresi berganda untuk lima variabel di mana variabel terikatnya merupakan fungsi linear dari empat variabel bebas.

\section{HASIL PENELITIAN DAN PEMBAHASAN}

\section{I Hasil Penelitian Analisis Risiko IHSG dan Kurs Dollar terhadap Return Saham Sektoral di BEI periode 2012 s.d 2016.}

\author{
4.I.I Analisis return IHSG di BEI periode 2012 \\ s.d 2016 \\ Dalam periode di tahun 2012 s.d 2016 ini
}


pergerakan Indeks Saham Gabungan (IHSG) terus bergerak naik dan turun.

\section{Grafik 4.I.I \\ Pergerakan Return IHSG periode 2012 s.d 2016}

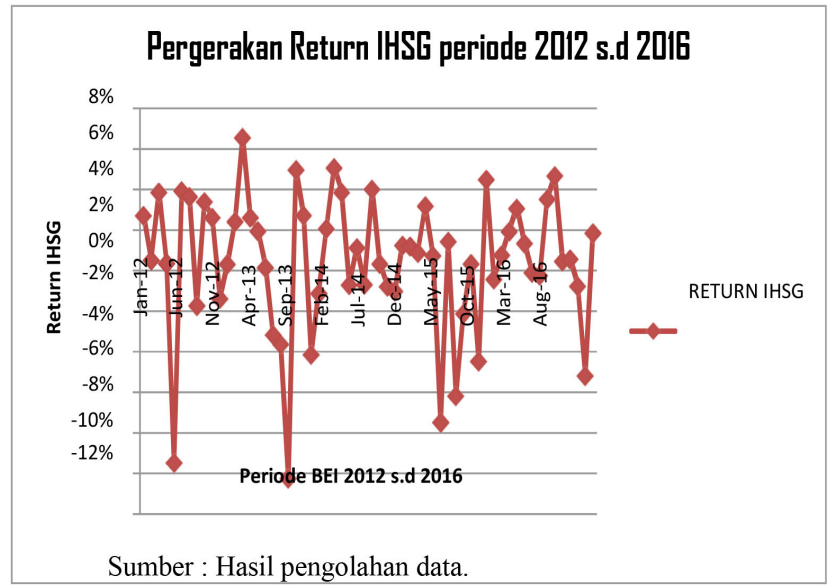

Dari tabel dan grafik diatas, diperoleh informasi bahwa nilai rata-rata return Indeks Harga Saham Gabungan periode 2012 s.d 2016 relatif stabil meskipun pada periode Mei 2012 dan Agustus 2013 merosot cukup signifikan diangka -9\% dan -

$10 \%$. Pada periode di atas diperoleh nilai return IHSG tertinggi pada level $7 \%$ dan nilai return IHSG terendah pada level $-10 \%$.

Jadi pada periode penelitian ini yaitu 2012 s.d 2016 dapat dilihat dari awal periode 2012 bahwa return IHSG berada pada level 3\%, mengalami volatilitas yang cukup tinggi namun mulai stabil kembali stabil pada level $2 \%$ pada periode 2016 akhir hal ini diluar faktor-faktor lain yang mempengaruhi seperti nilai perkembangan rupiah per dollar AS, aksi korporasi, dll.

\section{I.2 Analisis Pergerakan Kurs Dollar di BEI periode 2012 s.d 2016.}

Nilai tukar rupiah tentunya akan membawa banyak dampak pada perusahaan apalagi perusahaan yang memiliki kegiatan ekspor-impor atau perusahaan yang memiliki kegitan di luar negeri.

Pada perusahaan yang melakukan ekspor tentunya akan memiliki keuntungan trading margin dari harga jual dan harga beli nilai tukar rupiah, tetapi lain halnya dengan perusahaan yang melakukan kegiatan impor tentunya akan dirugikan karena perusahaan harus membeli dollar dengan harga yang tinggi.

Dengan harga rupiah yang rendah maka pada saat pembelian bahan baku tentunya akan mempertinggi biaya produksi, jika produk meningkat maka harga jual produk ikut meningkat.

Oleh karena itu, tidaklah mengherankan pada saat nilai tukar melemah maka hampir seluruh harga produk dipasaran ikut meningkat. Jika dilihat lebih jauh hal tersebut dapat merugikan perekonomian secara makro.

Dibawah ini grafik yang menunjukan perkembangan return nilai tukar rupiah per dollar AS periode 2012 s.d 2016

\section{Grafik 4.I.2}

Pergerakan Return Kurs Dollar Periode 2012 s.d 2016

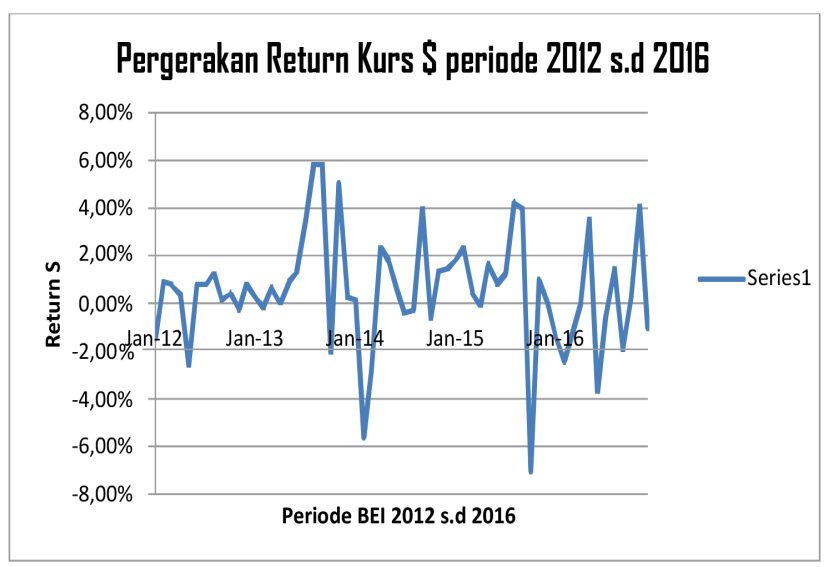

Sumber : Hasil pengolahan data.

Dari tabel dan grafik diatas, diperoleh informasi bahwa return nilai kurs rupiah per dollar AS selama periode 2012 s.d 2016 relatif stabil tetapi pada periode 2016 akhir cenderung sedikit melemah. Pada periode diatas diperoleh return nilai rupiah tertinggi pada level $6 \%$ per US\$ dan nilai rupiah terendah pada level $-7 \%$. Jadi rata-rata return nilai rupiah perUS $\$$ sebesar $0.48 \%$.

Jadi pada periode penelitian ini yaitu 2012 s.d 2016, dilihat dari tingkat return rupiah per dollar AS, perekonomian Indonesia bisa disebut tidak stabil diluar faktor- faktor lain yang mempengaruhi seperti tingkat return IHSG, aksi korporasi emiten dalam BEI dan faktor lainnya. 


\section{I.3 Statistik Deskriptif}

Statistik deskriptif adalah tampilan data secara ringkas dan dengan tujuan supaya mudah diinterpretasikan. Tampilan data dalam bentuk statistik rata-rata, deviasi standar, range dan distribusi nilai variabel atau distribusi variabel saja.

Sesuai dengan hasil analisis statistik deskriftif, maka karakteristik variabel penelitian ini dapat diuraikan sebagai berikut :

Table 4.I.3

Statistik Variabel $X_{1}, X_{2}$ dan $Y_{1} \ldots Y_{10}$

\begin{tabular}{|c|c|c|c|c|c|c|c|c|}
\hline & $\mathrm{N}$ & Range & Minimum & Maximum & Sum & Mean & Std. & Variance \\
\hline Variabel & & & & & & & Deviation & \\
\hline & Statistic & Statistic & Statistic & Statistic & Statistic & Statistic & Statistic & S tatistic \\
\hline $\mathrm{x} 1$ & 60 & 0.1678 & $(0.1023)$ & 0.0655 & 0.2599 & 0.0043 & 0.0343 & 0.0012 \\
\hline$\times 2$ & 60 & 0.1290 & $(0.0710)$ & 0.0580 & 0.2900 & 0.0048 & 0.0239 & 0.0006 \\
\hline $\mathrm{Y} 1$ & 60 & 0.3275 & (0.1928) & 0.1347 & $(0.2196)$ & $(0.0037)$ & 0.0742 & 0.0055 \\
\hline Y2 & 60 & 0.3798 & $(0.2457)$ & 0.1341 & -13.071 & $(0.0218)$ & 0.0672 & 0.0045 \\
\hline Y3 & 60 & 18.523 & -17.302 & 0.1221 & -19.196 & $(0.0320)$ & 0.2310 & 0.0534 \\
\hline Y4 & 60 & 0.2888 & $(0.1520)$ & 0.1368 & $(0.0076)$ & $(0.0001)$ & 0.0640 & 0.0041 \\
\hline Y5 & 60 & 0.2189 & $(0.0770)$ & 0.1419 & 0.4947 & 0.0082 & 0.0404 & 0.0016 \\
\hline Y6 & 60 & 0.3239 & (0.1913) & 0.1326 & 0.4717 & 0.0079 & 0.0751 & 0.0056 \\
\hline Y7 & 60 & 0.1712 & $(0.0974)$ & 0.0738 & 0.1414 & 0.0024 & 0.0415 & 0.0017 \\
\hline Y8 & 60 & 0.3061 & $(0.1673)$ & 0.1388 & 0.1958 & 0.0033 & 0.0576 & 0.0033 \\
\hline Y9 & 60 & 0.2167 & $(0.1124)$ & 0.1043 & 0.4519 & 0.0075 & 0.0469 & 0.0022 \\
\hline $\mathrm{Y} 10$ & 60 & 0.1984 & $(0.0997)$ & 0.0987 & 0.2248 & 0.0037 & 0.0426 & 0.0018 \\
\hline Valid N & 60 & & & & & & & \\
\hline (listwise) & & & & & & & & \\
\hline
\end{tabular}

Sumber : Hasil pengolahan data IBM SPSS 22.

Dari data statistik angket $X_{1}, X_{2}$ dan $Y_{1} \ldots Y_{10}$ berikut pemaparan untuk masing- masing variabel penelitian:

4.2 Return IHSG $\left(\mathbf{X}_{1}\right)$ : dari jumlah periode 60 bulan (2012 s/d 20I6), nilai min - 0.1023 dan tertinggi 0.0655 , jumlah 0.2599 , rata-rata 0.0043 , standar deviasi 0.0343 dan variasi data 0.0012

Return $\$\left(\mathbf{X}_{2}\right)$ : dari jumlah periode 60 bulan (20l2 s/d 20l6), nilai terendah - 0.07I0 dan tertinggi 0.0580 , jumlah 0.2900 , rata-rata 0.0048 , standar deviasi 0.0239 dan variasi data 0.006 .

Return saham Sektor Pertanian $\left(\mathbf{Y}_{1}\right)$ : dari jumlah periode 60 bulan (20I2 s/d 20I6), nilai terendah -0.1928 dan tertinggi 0.1347 , jumlah -0.2196 , rata-rata 0.0037 , standar deviasi 0.0742 dan variasi data 0.0055 .

Return saham Sektor Pertambangan $\left(\mathbf{Y}_{2}\right)$ : dari jumlah periode 60 bulan (20I2 s/d 20l6), nilai terendah
-0.2457 dan tertinggi 0.134 I, jumlah $-\mathrm{I} .307 \mathrm{I}$, ratarata -0.0218 , standar deviasi 0.0672 dan variasi data 0.0045 .

Return Saham Sektor Industri Dasar $\left(\mathbf{Y}_{3}\right)$ : dari jumlah periode 60 bulan (2012 s/d 2016), nilai terendah - I.7302 dan tertinggi 0.122I, jumlah - I.9196, ratarata -0.0320 , standar deviasi 0.2310 dan variasi data 0.0534 .

Return saham Sektor Aneka Industri $\left(\mathbf{Y}_{4}\right)$ : dari jumlah periode 60 bulan (20I2 s/d 20l6), nilai terendah -0.1520 dan tertinggi 0.1368 , jumlah -0.0076 , ratarata $-0.000 \mathrm{I}$, standar deviasi 0.0640 dan variasi data 0.0041

Return saham Sektor Konsumsi $\left(\mathbf{Y}_{5}\right)$ : dari jumlah periode 60 bulan (2012 s/d 20I6), nilai terendah -0.0770 dan tertinggi 0.1419 , jumlah 0.4947 , rata-rata 0.0082 , standar deviasi 0.0404 dan variasi data 0.016 .

Return Saham Sektor Property $\left(\mathbf{Y}_{6}\right)$ : dari jumlah periode 60 bulan (2012 s/d 2016), nilai terendah -0.1913 dan tertinggi 0.1326 , jumlah 0.1326 , rata-rata 0.0079 , standar deviasi 0.075 I dan variasi data 0.056 .

Return saham Sektoral Infrastruktur $\left(\mathbf{Y}_{7}\right)$ : dari jumlah periode 60 bulan (20I2 s/d 20l6), nilai terendah -0.0974 dan tertinggi 0.0738 , jumlah $0.14 \mid 4$, ratarata 0.0024 , standar deviasi 0.0415 dan variasi data 0.0017

Return Saham sektoral Keuangan $\left(\mathbf{Y}_{8}\right)$ : dari jumlah periode 60 bulan (2012 s/d 20l6), nilai terendah -0.1673 dan tertinggi 0.1388 , jumlah 0.1958 , ratarata 0.0033 , standar deviasi 0.0576 dan variasi data 0.0033 .

Return Saham Sektoral Perdagangan $\left(\mathbf{Y}_{q}\right)$ : dari jumlah periode 60 bulan (20I2 s/d 20l6), nilai terendah -0.1 I 24 dan tertinggi 0.1043 , jumlah 0.45 I 9 , ratarata 0.0075 , standar deviasi 0.0469 dan variasi data 0.022 .

Return Saham Sektoral Manufaktur $\left(\mathbf{Y}_{10}\right)$ : dari jumlah periode 60 bulan (2012 s/d 2016), nilai terendah 0.997 dan tertinggi 0.987 , jumlah 0.2248 , rata-rata 0.0037 , standar deviasi 0.0426 dan variasi data 0.018 .

\subsubsection{Korelasi AntarVariabel}

Uji korelasi ini bertujuan untuk mengetahui tingkat keeratan hubungan antara $x$ dan variabel $y$. Dari 
hasil olah data diperoleh nilai korelasi antara Return Saham IHSG dan Return \$ terhadap Return Saham-Saham Sektoral sebagai berikut :

Table 4.I.4.I Korelasi Antar Variabel Model Summary

\begin{tabular}{|c|c|c|c|c|c|c|c|c|c|}
\hline \multirow{3}{*}{ Model } & \multirow{3}{*}{$\mathrm{R}$} & \multirow{3}{*}{ R Square } & \multicolumn{2}{|c|}{ Adjusted Std. Error of } & \multirow{2}{*}{\multicolumn{5}{|c|}{ Change Statistics }} \\
\hline & & & \multirow{2}{*}{$\begin{array}{c}\mathrm{R} \\
\text { Square }\end{array}$} & \multirow{2}{*}{$\begin{array}{l}\text { the } \\
\text { Estimate }\end{array}$} & & & & & \\
\hline & & & & & & & & & \\
\hline & & & & & $\mathrm{R}$ & \multirow[b]{2}{*}{ F Change } & & \multirow[b]{2}{*}{$\mathrm{d} f 2$} & \multirow[b]{2}{*}{ Sig. F Change } \\
\hline & & & & & $\begin{array}{c}\text { Square } \\
\text { Change } \\
\end{array}$ & & df1 & & \\
\hline Y1 & $.183^{\mathrm{a}}$ & .033 & .000 & .0742328 & .033 & .986 & 2 & 57 & .379 \\
\hline Y2 & $.333^{\mathrm{a}}$ & .111 & .080 & .0644597 & .111 & 3.556 & 2 & 57 & .035 \\
\hline Y3 & $.098^{\mathrm{a}}$ & .010 & -.025 & .2339097 & .010 & .277 & 2 & 57 & .759 \\
\hline Y4 & $.590^{\mathrm{a}}$ & .349 & .326 & .0525243 & .349 & 15.250 & 2 & 57 & .000 \\
\hline Y5 & $.345^{\mathrm{a}}$ & .119 & .088 & .0385462 & .119 & 3.844 & 2 & 57 & .027 \\
\hline Y6 & $.659^{\mathrm{a}}$ & .435 & .415 & .0574130 & .435 & 21.914 & 2 & 57 & .000 \\
\hline Y7 & $.462^{\mathrm{a}}$ & .213 & .186 & .0374329 & .213 & 7.726 & 2 & 57 & .001 \\
\hline Y8 & $.721^{\mathrm{a}}$ & .520 & .503 & .0405952 & .520 & 30.817 & 2 & 57 & .000 \\
\hline Y9 & $.586^{\mathrm{a}}$ & .344 & .321 & .0386301 & .344 & 14.935 & 2 & 57 & .000 \\
\hline $\mathrm{Y} 10$ & $.610^{\mathrm{a}}$ & .372 & .349 & .0343739 & .372 & 16.846 & 2 & 57 & .000 \\
\hline
\end{tabular}

Sumber : Hasil pengolahan data IBM SPSS 22.

a. Predictors: (Constant), Kurs Dollar, IHSG

b. DependentVariables : Saham Sektoral (Pertanian, Pertambangan, Aneka Industri, Industri Dasar, Konsumsi, propeeti, infrastuktur, keuangan, Perdagangan, Manufaktur

Dari hasil perhitungan tabel Model Summary di atas diperoleh nilai korelasi antara return IHSG dan return Kurs Dollar terhadap return Saham Sektoral :

$Y_{1}-R_{\text {square }}$ Return ${ }_{\text {Saham Sektoral Pertanian }}=0.033$ atau 3.33 $\%$ artinya pengaruh return IHSG, return Kurs Dollar terhadap Return ${ }_{\text {Saham Sektoral Pertanian }}$ lemah.

Y2- $R_{\text {square }}$ Return ${ }_{\text {Saham Sektoral Pertambangan }}=0.1$ II atau I I.I \% artinya pengaruh return IHSG, return Kurs Dollar terhadap Return Saham Sektoral Pertambangan $_{\text {lemah. }}$ Y3- $R_{\text {square }}$ Return Saham Sektoral Industridasar $=0.010$ atau I $\%$ artinya pengaruh return IHSG, return Kurs Dollar terhadap Return saham Sektoral Industridasar lemah. Y3- $R_{\text {square }}$ Return Saham Sektoral Industridasar $=0.010$ atau I $\%$ artinya pengaruh return IHSG, return Kurs Dollar terhadap Return saham Sektoral Industridasar $_{\text {lemah. }}$

Y4- $\mathrm{R}_{\text {square }}$ Return ${ }_{\text {Saham SektoralAnekalndustri }}=0.349$ atau $34.9 \%$ artinya pengaruh return IHSG, return Kurs
\$ terhadap Return ${ }_{\text {Saham SektoralAnekalndustri }}$ cukup kuat. Y5- $R_{\text {square }}$ Return Saham Sektoral Konsumsi $_{\text {sat }}=0.119$ atau I I.9 $\%$ artinya pengaruh return IHSG, return Kurs Dollar terhadap Return saham Sektoral Konsumsi lemah.

Y6- $R_{\text {square }}$ Return Saham Sektoral Properti $=0.435$ atau 43.5 $\%$ artinya pengaruh return IHSG, return Kurs Dollar terhadap Return saham Sektoral Properti cukup kuat. Y7- $R_{\text {square }}$ Return Saham Sektoral Infrastruktur $=0.213$ atau $21.3 \%$ artinya pengaruh return IHSG, return Kurs Dollar terhadap Return ${ }_{\text {Saham Sektoral Infrastruktur }}$ lemah. Y8- $\mathrm{R}_{\text {square }}$ Return ${ }_{\text {Saham Sektoral Keuangan }}=0.520$ atau 52.0 $\%$ artinya pengaruh return IHSG, return Kurs Dollar terhadap Return ${ }_{\text {Saham Sektoral Keuangan }}$ kuat.

Y9- $R_{\text {square }}$ Return SahamSektoralPerdagangan $=0.344$ atau $34.4 \%$ artinya pengaruh return IHSG, return Kurs $\$$ terhadap Return ${ }_{\text {SahamSektoralPerdagangan }}$ cukup kuat. YIO- $R_{\text {square }}$ Return ${ }_{\text {Saham SektoralManufaktur }}=0.372$ atau 37.2 $\%$ artinya pengaruh return IHSG, return Kurs \$ terhadap Return ${ }_{\text {Saham Sektoralmanufaktur }}$ cukup kuat.

Berdasarkan tabel Model Summary tersebut juga diperoleh nilai probabilitas (sig.F change) :

Sig. $F_{Y|X| X 2}=0.379>0.05$, artinya : Ho diterima, $\mathrm{H}_{1}$ ditolak Sig. $\mathrm{F}_{Y_{2 \times 1 \times 2}}=0.035<0.05$, artinya : Ho ditolak, $\mathrm{H}_{1}$ diterima Sig. $\mathrm{F}_{Y 3 \times 1 \times 2}=0.759>0.05$, artinya : $\mathrm{Ho}$ diterima, $H_{1}$ ditolak Sig. $F_{Y 4 X 1 \times 2}=0.000<0.05$, artinya : Ho ditolak, $H_{1}$ diterima Sig. $F_{Y 5 \times 1 \times 2}=0.027<0.05$, artinya

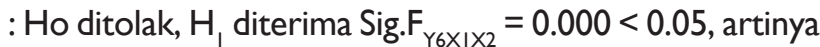
: Ho ditolak, $H_{1}$ diterima Sig. $F_{Y 7 X \mid X 2}=0.00 I<0.05$, artinya : Ho ditolak, $\mathrm{H}_{1}$ diterima Sig. $\mathrm{F}_{Y 8 \times 1 \times 2}=0.000<0.05$, artinya : Ho ditolak, $\mathrm{H}_{1}$ diterima Sig. $\mathrm{F}_{Y 9 X \mid X 2}=0.000<0.05$, artinya : Ho ditolak, $\mathrm{H}_{1}$ diterima Sig. $\mathrm{F}_{\mathrm{Y} \mid 0 \times 1 \times 2}=0.000<0.05$, artinya : Ho ditolak, $\mathrm{H}_{\text {, diterima }}$

\section{Penjelasan :}

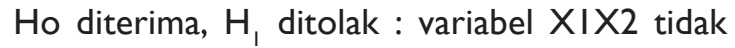
berhubungan secara simultan dan signifikan terhadap variabel $y$.

Ho ditolak, $H_{1}$ diterima : variabel $\times 1 \times 2$ berhubungan secara simultan dan signifikan terhadap variabel $y$.

Dengan demikian dapat disimpulkan juga Matriks Kolerasi Variabel-nya sebagai berikut : 
Table 4.I.4.2 Matrik Kolerasi

\begin{tabular}{|c|c|c|c|c|c|c|c|c|c|c|c|c|}
\hline & \multicolumn{12}{|c|}{ Matrix Correlations } \\
\hline Variabel & IHSG & $\$$ & Y1 & Y2 & $\mathrm{Y}_{3}$ & $\mathrm{Y}_{4}$ & Y5 & $Y_{6}$ & \begin{tabular}{|l}
$\mathrm{Y} 7$ \\
\end{tabular} & Y8 & $Y_{9}$ & Y10 \\
\hline IHSG & 1 & $-399^{4}$ & .183 & $.304^{\circ}$ & .074 & $.586^{\prime \prime}$ & $.345^{\prime \prime}$ & $.657^{\prime \prime}$ & $.462^{4}$ & $.720^{\circ}$ & $.574^{\prime \prime}$ & .608 \\
\hline$\$$ & $-399^{\prime \prime}$ & 1 & .071 & .004 & .030 & $-298^{\circ}-(-3)$ & -.142 & $-309^{\circ}$ & \begin{tabular}{|l|}
-194 \\
\end{tabular} & $-264^{\circ}$ & -119 & -284 \\
\hline Y1 & .183 & -.071 & 1 & & & & & & & & & \\
\hline Y2 & $.304^{\circ}$ & .004 & & 1 & & & & & & & & \\
\hline Y3 & .074 & .030 & & & 1 & & & & & & & \\
\hline$Y_{4}$ & $.586^{\prime \prime}$ & $-298^{\circ}$ & & & & 1 & & & & & & \\
\hline Y5 & $.345^{\prime \prime}$ & -.142 & & & & & 1 & & & & & \\
\hline$Y_{6}$ & $.657^{\prime \prime}$ & $-.309^{\circ}$ & & & & & & 1 & & & & \\
\hline Y7 & $.462^{\prime \prime}$ & -194 & & & & & & & 1 & & & \\
\hline Y8 & $.720^{\circ}$ & $-264^{\circ}$ & & & & & & & & 1 & & \\
\hline Ү9 & $.574^{\prime \prime}$ & -.119 & & & & & & & & & 1 & \\
\hline Y10 & $.608^{\prime \prime}$ & $-284^{4}$ & & & & & & & & & & 1 \\
\hline
\end{tabular}

Sumber : Hasil pengolahan data IBM SPSS 22.

\subsubsection{Analisis Linear Berganda}

Dengan menggunakan alat ukur pengolahan data IBM SPSS 22 sehingga diperoleh persamaan regresi berganda antara variabel independen $X_{1}$ (Return Saham IHSG) dan variabel independen $\mathrm{X}_{2}$ (Return Kurs Dollar) terhadap YI..YIO (Return Saham Sektoral) sebagai berikut:

Table 4.I.5 Analisis Linear Berganda
Nilai konstanta tersebut menunjukan nilai negative pada variabel return IHSG dan return \$.Apabila return IHSG dan Kurs Dollar naik maka return saham sektoral Pertanian akan turun.

Nilai koefisien regresi return IHSG dan Kurs Dollar tersebut menunjukan apabila jika return IHSG dan Kurs Dollar mengalami kenaikan I satuan maka return saham sektoral Pertanian akan mengalami kenaikan $39.85 \%$ dan $\mathbf{0 . 9 0 \%}$

2) $Y_{2}-$ Return Saham Sektoral Pertambangan $=-0.027+0.712$ IHSG + 0.418 \$ + e

Nilai konstanta tersebut menunjukan nilai negative pada variabel return IHSG dan return \$.Apabila return IHSG dan Kurs Dollar naik maka return saham sektoral perdagangan akan turun.

Nilai koefisien regresi return IHSG dan Kurs Dollar tersebut menunjukan apabila jika return IHSG dan Kurs Dollar mengalami kenaikan I satuan maka return saham sektoral Pertambangan akan mengalami kenaikan $71.22 \%$ dan $41.83 \%$.

3) $\quad Y_{3}-$ Return Saham Sektoral Industri Dasar $=-0.038+0.687$ IHSG + $0.683 \$+e$

\begin{tabular}{|c|c|c|c|c|c|c|}
\hline & \multirow{2}{*}{ Model } & \multicolumn{2}{|c|}{$\begin{array}{c}\text { Unstandardized } \\
\text { Coefficients }\end{array}$} & \multirow{2}{*}{\begin{tabular}{|c|}
$\begin{array}{c}\text { Standardized } \\
\text { Coefficients }\end{array}$ \\
Beta \\
\end{tabular}} & \multirow{2}{*}{$t$} & \multirow{2}{*}{ Sig. } \\
\hline & & $\mathrm{B}$ & Std. Error & & & \\
\hline \multirow[t]{3}{*}{$\overline{Y 1}$} & (Constant) & -.005 & .010 & & -.542 & .590 \\
\hline & IHSG & .398 & .308 & .184 & 1.296 & .200 \\
\hline & $\$$ & .009 & .441 & .003 & .020 & .984 \\
\hline
\end{tabular}

a. Dependent Variable: Return Saham Sektoral Pertanian

\begin{tabular}{|c|c|c|c|c|c|}
\hline Y2 (Constant) & -.027 & .009 & & -3.090 & .003 \\
IHSG & .712 & .267 & .363 & 2.667 & .010 \\
\hline$\$$ & .418 & .383 & .149 & 1.092 & .280 \\
\hline
\end{tabular}

b. Dependent Variable: Return Saham Sektoral

\begin{tabular}{|c|c|c|c|c|c|c|}
\hline \multirow[t]{3}{*}{$\mathrm{Y3}$} & (Constant) & -.038 & .032 & & -1.212 & .231 \\
\hline & IHSG & .687 & .969 & .102 & .708 & .482 \\
\hline & $\$$ & 683 & 1.391 & .071 & 491 & .625 \\
\hline
\end{tabular}

c. Dependent Variable: Return Saham Sektoral Industri

\begin{tabular}{|c|c|c|c|c|c|c|}
\hline \multirow[t]{3}{*}{$\longdiv { \mathrm { Y } 4 }$} & (Constant) & -.004 & .007 & & -.511 & .611 \\
\hline & IHSG & 1.037 & .218 & .556 & 4.765 & .000 \\
\hline & $\$$ & -.206 & .312 & -.077 & -.659 & .513 \\
\hline
\end{tabular}

d. Dependent Variable: Return Saham Sektoral Aneka

\begin{tabular}{|c|c|c|c|c|c|c|}
\hline \multirow[t]{3}{*}{$\longdiv { Y 5 }$} & (Constant) & .007 & .005 & & 1.257 & .214 \\
\hline & IHSG & .403 & .160 & .343 & 2.526 & .014 \\
\hline & $\$$ & -.009 & .229 & -.005 & -.040 & .968 \\
\hline
\end{tabular}

e. Dependent Variable: Return Saham Sektoral Konsumsi

Sumber : Hasil pengolahan data IBM SPSS 22.

Persamaan Regresi Berganda : $Y=a+\hat{a}_{1} X_{1}+\hat{a}_{2} X_{2}+e$

I) $Y_{1}-$ Return ${ }_{\text {Saham Sektoral Pertanian }}=-0.005+0.398$ IHSG $+0.009 \$+e$

\begin{tabular}{|c|c|c|c|c|c|c|}
\hline & \multirow{2}{*}{ Model } & \multicolumn{2}{|c|}{$\begin{array}{l}\text { Unstandardized } \\
\text { Coefficients }\end{array}$} & \multirow{2}{*}{$\begin{array}{c}\begin{array}{c}\text { Standardized } \\
\text { Coefficients }\end{array} \\
\text { Beta }\end{array}$} & \multirow[t]{2}{*}{$t$} & \multirow{2}{*}{ Sig. } \\
\hline & & $\mathrm{B}$ & Std. Error & & & \\
\hline \multirow[t]{3}{*}{$\overline{\mathrm{Y} 6}$} & (Constant) & .003 & .008 & & .345 & .732 \\
\hline & IHSG & 1.392 & .238 & .635 & 5.850 & .000 \\
\hline & $\$$ & -.173 & .341 & -.055 & -.507 & .614 \\
\hline
\end{tabular}

f. Dependent Variable: Return Saham Sektoral Property

\begin{tabular}{|c|r|r|r|r|r|r|}
\hline Y7 & (Constant) & .000 & .005 & & .012 & .990 \\
& IHSG & .553 & .155 & .457 & 3.566 & .001 \\
& $\$$ & -.021 & .223 & -.012 & -.093 & .926 \\
\hline
\end{tabular}

g. Dependent Variable: Return Saham Sektoral Infrastruktur

\begin{tabular}{|c|c|r|r|r|r|r|}
\hline Y8 (Constant) & -.002 & .005 & & -.435 & .665 \\
& (CHSG & 1.229 & .168 & .731 & 7.305 & .000 \\
& $\$$ & .067 & .241 & .028 & .278 & .782 \\
\hline
\end{tabular}

h. Dependent Variable: Return Saham Sektoral Keuangan

\begin{tabular}{|l|l|l|r|r|r|r|}
\hline Y9 (Constant) & .003 & .005 & & .495 & .623 \\
& X1 & .857 & .160 & .626 & 5.352 & .000 \\
& X2 & .257 & .230 & .131 & 1.119 & .268 \\
\hline
\end{tabular}

i. Dependent Variable: Return Saham Sektoral Perdagangan

\begin{tabular}{|c|c|c|c|c|c|c|}
\hline \multirow[t]{3}{*}{$\mathrm{Y} 10$} & (Constant) & .001 & .005 & & .217 & .829 \\
\hline & IHSG & .731 & .142 & .588 & 5.135 & .000 \\
\hline & $\$$ & -.088 & 204 & -.049 & -.432 & .667 \\
\hline
\end{tabular}

j. Dependent Variable: Return Saham Sektoral Manufaktur
Nilai konstanta tersebut menunjukan nilai negatif pada variabel return IHSG dan return \$. Apabila return IHSG dan Kurs Dollar naik maka return saham sektoral Industri Dasar akan turun.

Nilai koefisien regresi return IHSG dan Kurs Dollar tersebut menunjukan apabila jika return IHSG dan 
Kurs Dollar mengalami kenaikan I satuan maka return saham sektoral Industri Dasar akan mengalami kenaikan $68.65 \%$ dan $68.26 \%$.

$\mathrm{Y}_{4}-$ Return $_{\text {Saham Sektoral Aneka Industri }}=-0.004+1.037$ IHSG $+-0.206+\mathrm{e}$

Nilai konstanta tersebut menunjukan nilai negatif pada variabel return IHSG dan return \$. Apabila return IHSG dan Kurs Dollar naik maka return saham sektoral Aneka Industri akan turun

Nilai koefisien regresi return IHSG dan Kurs Dollar tersebut menunjukan apabila jika return IHSG dan Kurs Dollar mengalami kenaikan I satuan maka return saham sektoral Industri Dasar akan mengalami kenaikan $103.70 \%$ dan penurunan $20.57 \%$.

5) $Y_{5}-$ Return ${ }_{\text {Saham Sektoral Konsumsi }}=0.007+0.403 \mathrm{IHSG}$ $+-0.009 \$+\mathrm{e}$

Nilai konstanta tersebut menunjukan nilai positive pada variabel return IHSG dan return \$.Apabila return IHSG dan Kurs Dollar naik maka return saham sektoral Konsumsi akan naik.

Nilai koefisien regresi return IHSG dan Kurs Dollar tersebut menunjukan apabila jika return IHSG dan Kurs Dollar mengalami kenaikan I satuan maka return saham sektoral Konsumsi akan mengalami kenaikan $40.35 \%$ dan penurunan $-0.92 \%$.

6) $Y_{6}-$ Return ${ }_{\text {Saham Sektoral Properti }}=0.003+1.392$ IHSG $+-0.173 \$+\mathrm{e}$

Nilai konstanta tersebut menunjukan nilai positive pada variabel return IHSG dan return \$.Apabila return IHSG dan Kurs Dollar naik maka return saham sektoral Properti akan naik.

Nilai koefisien regresi return IHSG dan Kurs Dollar tersebut menunjukan apabila jika return IHSG dan Kurs Dollar mengalami kenaikan I satuan maka return saham sektoral Properti akan mengalami kenaikan $139.16 \%$ dan penurunan $-17.31 \%$.

7) $Y_{7}-$ Return Saham Sektoral Infrastruktur $=0.000+0.553$ IHSG + - $0.021 \$+e$

Nilai konstanta tersebut menunjukan nilai positive pada variabel return IHSG dan return \$.Apabila return IHSG dan Kurs Dollar naik maka return saham sektoral Infrastruktur akan naik.

Nilai koefisien regresi return IHSG dan Kurs Dollar tersebut menunjukan apabila jika return IHSG dan
Kurs Dollar mengalami kenaikan I satuan maka return saham sektoral Infrastruktur akan mengalami kenaikan $55.31 \%$ dan penurunan $2.07 \%$.

8) $Y_{8}-$ Return ${ }_{\text {Saham Sektoral Keuangan }}=-0.002+1.229$ IHSG $+0.067 \$+\mathrm{e}$

Nilai konstanta tersebut menunjukan nilai negative pada variabel return IHSG dan return \$.Apabila return IHSG dan Kurs Dollar naik maka return saham sektoral Keuangan akan turun.

Nilai koefisien regresi return IHSG dan Kurs Dollar tersebut menunjukan apabila jika return IHSG dan Kurs Dollar mengalami kenaikan I satuan maka return saham sektoral Keuangan akan mengalami kenaikan $122.87 \%$ dan $6.71 \%$.

$\mathrm{Y}_{9}-$ Return $_{\text {Saham Sektoral Perdagangan }}=0.003+0.857 \mathrm{IHSG}$ $+0.257 \$+e$

Nilai konstanta tersebut menunjukan nilai positive pada variabel return IHSG dan return \$.Apabila return IHSG dan Kurs Dollar naik maka return saham sektoral Perdagangan akan naik.

Nilai koefisien regresi return IHSG dan Kurs Dollar tersebut menunjukan apabila jika return IHSG dan Kurs Dollar mengalami kenaikan I satuan maka return saham sektoral Perdagangan akan mengalami kenaikan $85.65 \%$ dan $25.69 \%$.

10) $Y_{10}-$ Return ${ }_{\text {Saham Sektoral Manufaktur }}=0.01+0.73$ I IHSG $+-0.088 \$+e$

Nilai konstanta tersebut menunjukan nilai positive pada variabel return IHSG dan return \$.Apabila return IHSG dan Kurs Dollar naik maka return saham sektoral Manufaktur akan naik.

Nilai koefisien regresi return IHSG dan Kurs Dollar tersebut menunjukan apabila jika return IHSG dan Kurs Dollar mengalami kenaikan I satuan maka return saham sektoral Infrastruktur akan mengalami kenaikan $73.13 \%$ dan penurunan $8.83 \%$.

\subsubsection{Alat Analisis Data}

4.I.6.I. Perhitungan Tingkat Suku Bunga SBI, dengan mencari Risk Free Rate dirangkum dalam tabel sebagai berikut 
Tabel 4. I.6. I Tingkat Suku Bunga Bebas Risiko 2012 s.d 2016

\begin{tabular}{|c|c|c|c|c|c|c|}
\hline \multirow{2}{*}{ Periode } & \multicolumn{5}{|c|}{ Risk Free Rate (SBI) } & \\
\hline & 2012 & 2013 & 2104 & 2015 & 2016 & \\
\hline Desember & 0.0575 & 0.0750 & 0.0775 & 0.0750 & 0.0650 & \\
\hline November & 0.0575 & 0.0750 & 0.0750 & 0.0750 & 0.0650 & \\
\hline Oktober & 0.0575 & 0.0725 & 0.0750 & 0.0750 & 0.0650 & \\
\hline September & 0.0575 & 0.0725 & 0.0750 & 0.0750 & 0.0650 & \\
\hline Agustus & 0.0575 & 0.0700 & 0.0750 & 0.0750 & 0.0650 & \\
\hline Juli & 0.0575 & 0.0650 & 0.0750 & 0.0750 & 0.0650 & \\
\hline Juni & 0.0575 & 0.0600 & 0.0750 & 0.0750 & 0.0650 & \\
\hline Mei & 0.0575 & 0.0575 & 0.0750 & 0.0750 & 0.0675 & \\
\hline Aprik & 0.0575 & 0.0575 & 0.0750 & 0.0750 & 0.0675 & \\
\hline Maret & 0.0575 & 0.0575 & 0.0750 & 0.0750 & 0.0675 & \\
\hline Februari & 0.0575 & 0.0575 & 0.0750 & 0.0750 & 0.0700 & \\
\hline Januari & 0.0600 & 0.0575 & 0.0750 & 0.0775 & 0.0725 & Total \\
\hline Jumlah & 0.6925 & 0.7775 & 0.9025 & 0.9025 & 0.8000 & 4.0750 \\
\hline
\end{tabular}

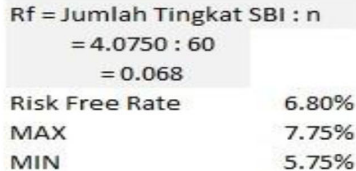

Sumber : www.bi.go.id

Berdasarkan perhitungan diatas terlihat bahwa ratarata return aset bebas risiko $(\mathrm{Rf})$ yang diterima investor periode $2012 \mathrm{~s} / \mathrm{d} 2016$ adalah 0.068 atau $6.80 \%$ per tahun yang meliputi suku bunga minimum $5.75 \%$ dan maximum $7.75 \%$.

\section{I.6.2 Perhitungan Market Return dirangkum dalam perhitungan tabel sebagai berikut :} Tabel 4.1.6.2

\begin{tabular}{|c|c|c|c|c|c|c|}
\hline \multirow[t]{2}{*}{ Periode } & \multicolumn{5}{|c|}{$\begin{array}{l}\text { Return Pasar Jakarta Composite Index (IHSG) } \\
\text { Periode 2012 - } 2016\end{array}$} & \\
\hline & 2012 & 2013 & 2014 & 2015 & 2016 & \\
\hline Jan & 0.0271 & 0.0241 & 0.0207 & 0.0088 & 0.0193 & \\
\hline Feb & 0.0051 & 0.0655 & 0.0506 & 0.0319 & 0.0307 & \\
\hline Mar & 0.0386 & 0.0262 & 0.0386 & 0.0074 & 0.0135 & \\
\hline Apr & 0.0035 & 0.0195 & -0.0070 & -0.0748 & -0.0010 & \\
\hline May & -0.0947 & 0.0015 & 0.0113 & 0.0144 & -0.0024 & \\
\hline Jun & 0.0394 & -0.0316 & -0.0069 & -0.0617 & 0.0353 & \\
\hline Jul & 0.0364 & -0.0362 & 0.0401 & -0.0211 & 0.0469 & \\
\hline Aug & -0.0173 & -0.1023 & 0.0034 & 0.0034 & 0.0045 & \\
\hline Sep & 0.0339 & 0.0498 & -0.0078 & -0.0446 & 0.0056 & \\
\hline Oct & 0.0262 & 0.0273 & -0.0101 & 0.0450 & -0.0076 & \\
\hline Nov & -0.0138 & -0.0414 & 0.0125 & -0.0042 & -0.0519 & \\
\hline Dec & 0.0033 & -0.0112 & 0.0120 & 0.0077 & 0.0185 & Total \\
\hline AVERAGE & 0.0073 & -0.0007 & 0.0131 & -0.0073 & 0.0093 & 0.0043 \\
\hline VARIANCE & 0.0014 & 0.0022 & 0.0004 & 0.0013 & 0.0006 & 0.0012 \\
\hline$\delta m$ & 0.0379 & 0.0465 & 0.0207 & 0.0365 & 0.0253 & 0.0334 \\
\hline
\end{tabular}

Return Market IHSG periode 2012 s.d 2016

Sumber : Hasil pengolahan data.
Dari hasil rata-rata return market IHSG di atas menunjukan sentimen pasar yang positif di masing-masing sektoral meskipun pergerakannya kecil.

\section{I.6.3 Perhitungan Market Return dirangkum dalam perhitungan tabel sebagai berikut :}

Tabel 4.I.6.3

Return Saham Sektoral periode 2012 s.d 2016

\section{I.6.4 Perhitungan Sensivitas Beta Saham}

Tabel 4.1.6.4

Perhitungan Beta Saham Sektoral BEI periode 2012 s.d 2016

\begin{tabular}{|c|l|l|r|r|r|r|c|}
\hline Variable & Name Of Stocks & Rf & $\begin{array}{c}\text { Stock's rate } \\
\text { of return }\end{array}$ & $\begin{array}{c}\text { Market rate } \\
\text { of Return } \\
\text { (IHSG) }\end{array}$ & Beta & Status & Sensitivity \\
\hline \hline Y1 & Pertanian & 0.068 & $(0.004)$ & 0.0043 & 1.13 & $>1$ & High \\
\hline Y2 & Pertambangan & 0.068 & $(0.022)$ & 0.0043 & 1.41 & $>1$ & High \\
\hline Y3 & Industri Dasar & 0.068 & $(0.032)$ & 0.0043 & 1.57 & $>1$ & High \\
\hline Y4 & Aneka Industri & 0.068 & $(0.000)$ & 0.0043 & 1.07 & $>1$ & High \\
\hline Y5 & Konsumsi & 0.068 & 0.008 & 0.0043 & 0.94 & $<1$ & Low \\
\hline Y6 & Properti & 0.068 & 0.008 & 0.0043 & 0.94 & $<1$ & Low \\
\hline Y7 & Infrastruktur & 0.068 & 0.002 & 0.0043 & 1.03 & $>1$ & High \\
\hline Y8 & Keuangan & 0.068 & 0.003 & 0.0043 & 1.02 & $>1$ & High \\
\hline Y9 & Perdagangan & 0.068 & 0.008 & 0.0043 & 0.95 & $<1$ & Low \\
\hline Y10 & Manufaktur & 0.068 & 0.004 & 0.0043 & 1.01 & $>1$ & High \\
\hline
\end{tabular}

Sumber : Hasil pengolahan data.

Dari hasil perhitungan di atas terlihat bahwa rata-rata return saham-saham sektoral periode 2012 s.d 2016 yang diterima oleh investor dalam 5 tahun berada dalam kategori yang positif meskipun nilainya tidak terlalu besar. Standar deviasi dalam perhitungan di atas menunjukan tingkat risiko saham, semakin besarnya standar deviasinya maka semakin besar pula risiko setiap saham.

Berdasarkan hasil perhitungan sebagaimana disajikan dalam tabel 4.I.6.4 di atas terlihat dari I0 jenis saham sektoral terdapat 7 jenis saham sektoral yang dikategorikan sebagai saham yang sensitif karena nilai âeta-nya berada di atas I (satu). Saham - saham dengan nilai â > I tersebut sangat sensitif terhadap pasar sehingga apabila pasar secara keseluruhan naik I (satu) poin maka saham-saham sektoral tersebut ikut naik menjadi lebih besar >I poin, begitu pula sebaliknya. 


\section{I.6.5 Perhitungan Harga Keseimbangan (CAPM)}

Setiap investor memiliki risk profile masing-masing yang dalam kenyataannya para investor tersebut berupaya memilih investasi yang berisiko lebih kecil jika dihadapkan pada dua pilihan investasi yang memberikan return yang sama dengan risiko yang berbeda. Investor dapat menilai hubungan antara risiko dan return tersebut dengan menggunakan pendekatan Capital Assets Pricing Model (CAPM) untuk menilai pilihan investasi yang layak.

Adapun perhitungan dengan menggunakan CAPM dirangkum dalam tabel sebagai berikut :

\section{Tabel 4.I.6.5 Perhitungan CAPM (Required Return) periode 2012 s.d 2016}

\begin{tabular}{l|c|c|c|c|c|c|c|c|c|}
$\begin{array}{c}\text { Sectoral Index } \\
\text { Stocks }\end{array}$ & Rf & $\begin{array}{c}\text { Market rate of } \\
\text { Return (IHSG) }\end{array}$ & Beta & rm-Rf & $\beta\{$ rm-Rf\} & CAPM & Status & Category & $\begin{array}{l}\text { Excess } \\
\text { Return }\end{array}$ \\
\hline \hline Pertanian & 0.068 & 0.0043 & 1.13 & $(0.0637)$ & $(0.0717)$ & $(0.0037)$ & $<$ Rm & Low & $(0.0080)$ \\
\hline Pertambangan & 0.068 & 0.0043 & 1.41 & $(0.0637)$ & $(0.0898)$ & $(0.0218)$ & $<$ Rm & Low & $(0.0261)$ \\
\hline Industri Dasar & 0.068 & 0.0043 & 1.57 & $(0.0637)$ & $(0.1000)$ & $(0.0320)$ & $<$ Rm & Low & $(0.0363)$ \\
\hline Aneka Industri & 0.068 & 0.0043 & 1.07 & $(0.0637)$ & $(0.0681)$ & $(0.0001)$ & $<$ Rm & Low & $(0.0045)$ \\
\hline Konsumsi & 0.068 & 0.0043 & 0.94 & $(0.0637)$ & $(0.0598)$ & 0.0082 & $>$ Rm & High & 0.0039 \\
\hline Properti & 0.068 & 0.0043 & 0.94 & $(0.0637)$ & $(0.0601)$ & 0.0079 & $>$ Rm & High & 0.0035 \\
\hline Infrastruktur & 0.068 & 0.0043 & 1.03 & $(0.0637)$ & $(0.0656)$ & 0.0024 & $<$ Rm & Low & $(0.0020)$ \\
\hline Keuangan & 0.068 & 0.0043 & 1.02 & $(0.0637)$ & $(0.0647)$ & 0.0033 & $<$ Rm & Low & $(0.0011)$ \\
\hline Perdagangan & 0.068 & 0.0043 & 0.95 & $(0.0637)$ & $(0.0605)$ & 0.0075 & $>$ Rm & High & 0.0032 \\
\hline Manufaktur & 0.068 & 0.0043 & 1.01 & $(0.0637)$ & $(0.0643)$ & 0.0037 & $<$ Rm & Low & $(0.0006)$ \\
\hline
\end{tabular}

CAPM bertahan bahwa harga saham tidak akan dipengaruhi oleh unsystematic risk, dan saham yang menawarkan risiko yang relatif lebih tinggi (higher âs) akan dihargai relatif lebih daripada saham yang menawarkan risiko lebih rendah (lower âs). Riset empiris mendukung argumen mengenai âs sebagai prediktor yang baik untuk memprediksi nilai saham di masa yang akan datang (future stock prices).

$$
r j=R f+\beta[r m-R f]
$$

Perhitungan CAPM adalah sbb :

\section{I.6.6 Perhitungan Excess Return}

Setelah mengetahui besarnya required return dari tabel 4.I.6.5 di atas selanjutnya adalah menghitung Ex- cess Return. Excess Return adalah selisih antara return yang diharapkan dari suatu saham tersebut dengan return pasar.

Nilai dari excess return masing-masing saham sektoral dapat dilihat pada tabel di bawah ini :

Tabel 4.1.6.6

Perhitungan Excess Return Saham Sektoral periode 2012 s.d 2016

\begin{tabular}{|l|c|c|c|r|}
\hline $\begin{array}{c}\text { Sectoral Index } \\
\text { Stocks }\end{array}$ & $\begin{array}{c}\text { Market } \\
\text { rate of } \\
\text { Return } \\
\text { (IHSG) }\end{array}$ & CAPM & Status & $\begin{array}{r}\text { Excess } \\
\text { Return }\end{array}$ \\
\hline \hline Pertanian & 0.0043 & $(0.0037)$ & $<\mathrm{Rm}$ & $(0.0080)$ \\
\hline Pertambangan & 0.0043 & $(0.0218)$ & $<\mathrm{Rm}$ & $(0.0261)$ \\
\hline Industri Dasar & 0.0043 & $(0.0320)$ & $<\mathrm{Rm}$ & $(0.0363)$ \\
\hline Aneka Industri & 0.0043 & $(0.0001)$ & $<\mathrm{Rm}$ & $(0.0045)$ \\
\hline Konsumsi & 0.0043 & 0.0082 & $>\mathrm{Rm}$ & $\mathbf{0 . 0 0 3 9}$ \\
\hline Properti & 0.0043 & 0.0079 & $>\mathrm{Rm}$ & $\mathbf{0 . 0 0 3 5}$ \\
\hline Infrastruktur & 0.0043 & 0.0024 & $<\mathrm{Rm}$ & $(0.0020)$ \\
\hline Keuangan & 0.0043 & 0.0033 & $<\mathrm{Rm}$ & $(0.0011)$ \\
\hline Perdagangan & 0.0043 & 0.0075 & $>\mathrm{Rm}$ & $\mathbf{0 . 0 0 3 2}$ \\
\hline Manufaktur & 0.0043 & 0.0037 & $<\mathrm{Rm}$ & $(0.0006)$ \\
\hline
\end{tabular}

Sumber : Hasil pengolahan data.

Apabila nilai excess return menunjukan hasil yang positif maka hal tersebut menggambarkan bahwa investor berpeluang melanjutkan investasi saham tersebut karena return yang diterima melebihi return yang diharapkan dan apabila nilai excess return menunjukan hasil yang negatif maka investor ada peluang mendapatkan kerugian dari investasi saham tersebut karena return yang diterima lebih kecil dari return yang diharapkan.

\section{Uji Normalitas.}

Table 4.I.7

Uji Normalitas Kolmogorov-Smirnov One-Sample Kolmogorov-Smirnov Test

\begin{tabular}{|l|r|r|r|}
\hline $\begin{array}{r}\text { Y1 - Return Saham } \\
\text { Sektoral Pertanian }\end{array}$ & $\begin{array}{c}\text { Unstandardized } \\
\text { Residual }\end{array}$ \\
\hline Asymp. Sig. (2-tailed) & $.200^{\text {c,0 }}$ \\
\hline Y6-Return Saham & Unstandardized \\
Sektoral Properti & Residual \\
\hline Asymp. Sig. (2-talled) & $.200^{c, 0}$ \\
\hline
\end{tabular}




\begin{tabular}{|c|c|c|c|}
\hline $\begin{array}{c}\text { Y2 - Return Saham } \\
\text { Sektoral } \\
\text { Pertambangan }\end{array}$ & $\begin{array}{c}\text { Unstandardized } \\
\text { Residual }\end{array}$ & $\begin{array}{l}\text { Y7 - Return Saham } \\
\text { Sektoral Infrastruktur }\end{array}$ & $\begin{array}{c}\text { Unstandardized } \\
\text { Residual }\end{array}$ \\
\hline Asymp. Sig. (2-tailed) & $.200^{c, d}$ & Asymp. Sig. (2-tailed) & $.200^{c, d}$ \\
\hline $\begin{array}{c}\text { Y3 - Return Saham } \\
\text { Sektoral Industri } \\
\text { Dasar }\end{array}$ & $\begin{array}{c}\text { Unstandardized } \\
\text { Residual }\end{array}$ & $\begin{array}{l}\text { Y8 - Return Saham } \\
\text { Sektoral Keuangan }\end{array}$ & $\begin{array}{l}\text { Unstandardized } \\
\text { Residual }\end{array}$ \\
\hline Asymp. Sig. (2-tailed) & $.000^{\circ}$ & Asymp. Sig. (2-tailed) & $.007^{\circ}$ \\
\hline $\begin{array}{c}\text { Y4 - Return Saham } \\
\text { Sektoral Aneka } \\
\text { Industri }\end{array}$ & $\begin{array}{c}\text { Unstandardized } \\
\text { Residual }\end{array}$ & $\begin{array}{c}\text { Y9 - Return Saham } \\
\text { Sektoral } \\
\text { Perdagangan }\end{array}$ & $\begin{array}{l}\text { Unstandardized } \\
\text { Residual }\end{array}$ \\
\hline Asymp. Sig. (2-tailed) & $.200^{c, d}$ & Asymp. Sig. (2-tailed) & $.200^{c, d}$ \\
\hline $\begin{array}{l}\text { Y5 - Return Saham } \\
\text { Sektoral Konsumsi }\end{array}$ & $\begin{array}{c}\text { Unstandardized } \\
\text { Residual }\end{array}$ & $\begin{array}{l}\text { Y10 - Return Saham } \\
\text { Sektoral Manufaktur }\end{array}$ & $\begin{array}{c}\text { Unstandardized } \\
\text { Residual }\end{array}$ \\
\hline Asymp. Sig. (2-tailed) & $.200^{c, d}$ & Asymp. Sig. (2-tailed) & $.011^{c}$ \\
\hline
\end{tabular}

c. Lilliefors Significance Correction.

d. This is a lower bound of the true significance.

Sumber : Hasil pengolahan data IBM SPSS 22.

Uji normalitas ini untuk melihat apakah nilai residual terdistribusi normal atau tidak normal. Model regresi yang baik adalah memiliki nilai residual yang 72

terdistribusi normal. Jadi uji normalitas disini yaitu uji normalitas Kolmogorov- Smirnov.

Kriteria pengujian yang dijadikan sebagai dasar pengambilan keputusan ini yaitu jika signifikan $>0.05$ maka $\mathrm{H} 0$ tidak ditolak, tetapi jika signifikan $<0.05$ maka HO ditolak.

Dari hasil uji normalitas dalam tabel 4.I.7 dapat diketahui bahwa nilai signifikan :

Return saham Sektor Pertanian $\left(\mathrm{Y}_{1}\right):$ nilai residual berdistribusi normal.

Return Saham Sektor Pertambangan $\left(\mathrm{Y}_{2}\right):$ nilai residual berdistribusi normal.

- Return saham Sektor IndustriDasar $\left(\mathrm{Y}_{3}\right)$ : $>$ nilai residual berdistribusi normal.

Return Saham Sektor Aneka Industri $\left(\mathrm{Y}_{4}\right)$ : nilai residual berdistribusi normal.

Return saham Sektor Konsumsi $\left(\mathrm{Y}_{5}\right)$ : nilai residual berdistribusi normal.

Return saham Sektor Properti $\left(\mathrm{Y}_{6}\right)$ : nilai residual berdistribusi normal.

Return Saham Sektor Infrastruktur $\left(\mathrm{Y}_{7}\right)$ : $>$ nilai residual berdistribusi normal.

Return saham Sektor Keuangan $\left(\mathrm{Y}_{8}\right)$ : nilai residual berdistribusi normal.

Return saham Sektor Perdagangan $\left(\mathrm{Y}_{9}\right)$ : nilai residual berdistribusi normal.

Return Saham Sektor Manufaktur $\left(\mathrm{Y}_{10}\right)$ : $>$ nilai residual berdistribusi normal.

Adapun hasil uji normalitas data pada grafik 4. I.7. Histogram dan Plot dari nilai residual dapat dilihat pada gambar di bawah ini :
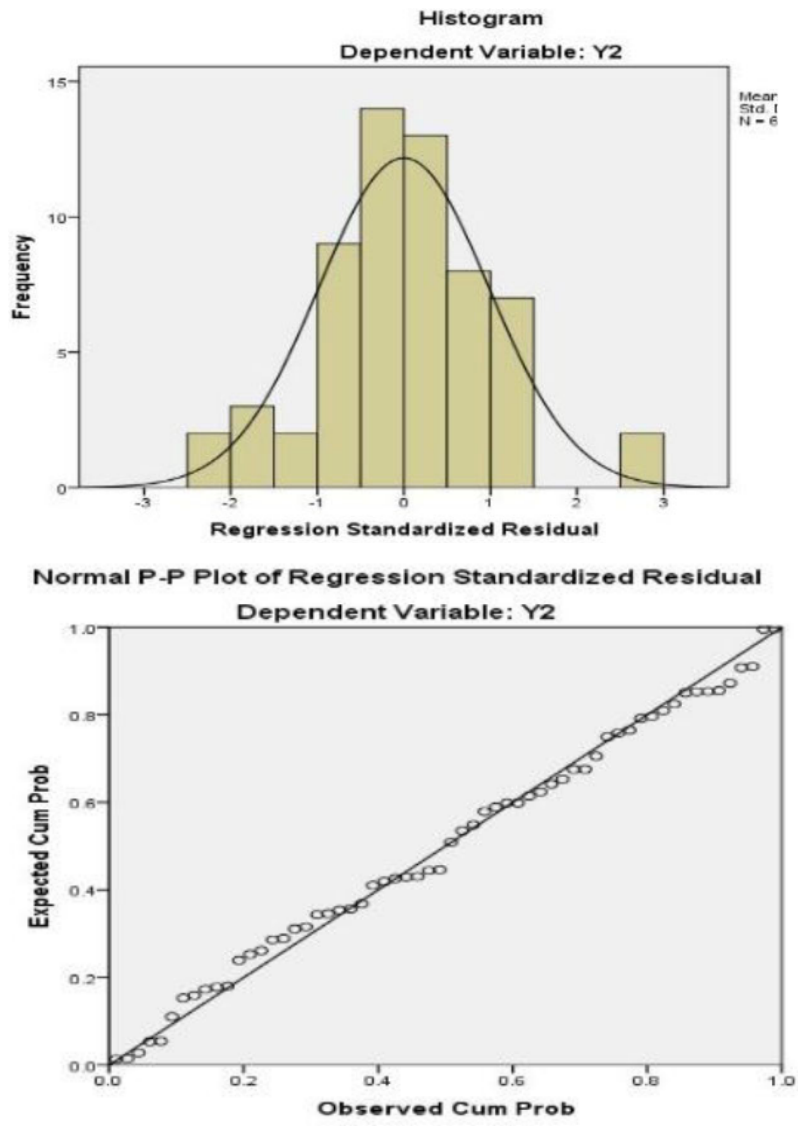

Sumber : Hasil pengolahan data IBM SPSS 22. (Y2)

Berdasarkan hasil histogram normalitas di atas yang membentuk kurve normal dan sebagian besar bar/batang berada di bawah kurva maka dapat diartikan bahwa variabel Return Saham Sektoral Pertambangan berdistribusi normal. 
Hal ini diartikan sama dengan hasil scatter plot di atas dimana plot-plot mengikuti garis fit line, kondisi ini masuk ke dalam kategori Perfect Positive Corelation antara variabel independen dan variabel dependen.

\subsubsection{Uji Autokorelasi}

Hasil Uji Autokorelasi dari penelitian ini dapat dilihat dari tabel sebagai berikut :

Table 4.I.8.

\section{Uji AutoKorelasi - Durbin Watson}

\begin{tabular}{|c|c|c|c|c|c|c|c|c|c|c|}
\hline \multicolumn{11}{|c|}{ Model Summary } \\
\hline & \multirow[b]{2}{*}{$\mathrm{R}$} & \multirow[b]{2}{*}{ R Square } & \multirow{2}{*}{\begin{tabular}{|l|} 
Adjusted \\
RSquare
\end{tabular}} & \multirow{2}{*}{$\begin{array}{l}\text { Sidd EIror } \\
\text { ofthe } \\
\text { Estimate }\end{array}$} & \multirow[b]{2}{*}{ DU } & \multirow{2}{*}{$\begin{array}{l}\text { Durbin- } \\
\text { Watson }\end{array}$} & \multirow[b]{2}{*}{ DL } & \multicolumn{3}{|c|}{ Autokorelasi } \\
\hline & & & & & & & & Ada & Tidak Ada & \begin{tabular}{|l|} 
Tidak Ada \\
Kesimpulan
\end{tabular} \\
\hline $\mathrm{Y1}$ & $.183^{\circ}$ & .033 & .000 & \begin{tabular}{|l|l|}
.0742328 \\
\end{tabular} & 1.2218 & 2.254 & 1.984 & $\bar{v}$ & & \\
\hline Y2 & $.333^{\circ}$ & .111 & .080 & \begin{tabular}{|l|l|}
.0644597 \\
\end{tabular} & 1.2218 & 1.854 & 1.984 & & v & \\
\hline $\mathrm{Y} 33_{3}$ & $.098^{4}$ & .010 & -025 & \begin{tabular}{|l|}
.2339097 \\
\end{tabular} & 1.2218 & 1.061 & 1.984 & $\sqrt{ }$ & & \\
\hline$Y_{4}$ & $.590^{\circ}$ & 349 & 328 & .0525243 & 1.2218 & 1.801 & 1.984 & & & $\sqrt{v}$ \\
\hline Y5 & $345^{5}$ & .119 & .088 & .0385462 & 1.2218 & 1.912 & 1.984 & $\mathrm{~V}$ & & \\
\hline 186 & $.659^{\circ}$ & 435 & .415 & .0574130 & 1.2218 & 2.029 & 1.984 & & 1 & \\
\hline 17 & $462^{2}$ & 213 & .186 & \begin{tabular}{|l|}
.0374329 \\
\end{tabular} & 1.2218 & 1.746 & 1.984 & & & V \\
\hline 18 & $.721^{4}$ & .520 & .503 & .0405952 & 1.2218 & 1.942 & 1.984 & & & $\bar{v}$ \\
\hline Y9 & $.586^{\circ}$ & 344 & 321 & . 0386301 & 1.2218 & 1.807 & 1.984 & & & v \\
\hline Y10 & $.610^{\circ}$ & 372 & 349 & \begin{tabular}{|l|l|}
.0343739 \\
\end{tabular} & 1.2218 & 1.866 & 1.984 & & & v \\
\hline
\end{tabular}

a redicors. (Constant), Return Kurs Dollar, Retum IHSG

b. Dependent Variable: Return Saham Seltoral

Keterangan :

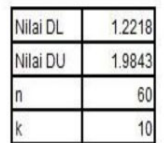

Sumber : Hasil pengolahan data IBM SPSS 22.

Pengujian Autokorelasi tersebut dilihat dari output Durbin-Watson (DW) dengan ketentuan :

$\checkmark \quad$ Bila nilai DW terletak antara batas atas atau upper bound (du) dan (4 - du), maka koefisien autokorelasi sama dengan nol, berarti tidak ada autokorelasi.

$\checkmark \quad$ Bila nilai DW lebih rendah daripada batas bawah atau lower bound (dl), maka koefisien autokorelasi lebih besar daripada nol, berarti ada autokorelasi positif.

$\checkmark \quad$ Bila nilai DW lebih besar daripada (4 - dl), maka koefisien autokorelasi lebih kecil daripada nol, berarti ada autokorelasi negatif.

$\checkmark \quad$ Bila nilai DW terletak di antara batas atas (du) dan batas bawah (d) ada DW terletak antara (4 - du) dan (4 - dl), maka hasilnya tidak dapat disimpulkan.

\subsubsection{Uji Heteroskedastisitas}

Untuk mendeteksi ada tidaknya heteroskedastisitas dalam model regesi maka dalam penelitian ini digunakan uji Glejser. Adapun hasil uji Glejser tersebut dirangkum dalam tabel berikut :

Tabel 4.I.9

\section{Uji Heteroskedastisitas}

\begin{tabular}{|c|c|c|c|c|}
\hline \multicolumn{5}{|c|}{ Coefficients $^{\mathrm{a}}$} \\
\hline \multicolumn{2}{|c|}{ Variable } & Sig. & Nilai (0.05) & Heteroskedastisitas \\
\hline \multirow{2}{*}{$\begin{array}{l}\text { Y1 Sektor } \\
\text { Pertanian }\end{array}$} & IHSG & .200 & $>0.05$ & Tidak Ada \\
\hline & $\$$ & .984 & $>0.05$ & Tidak Ada \\
\hline \multirow{2}{*}{$\begin{array}{c}\text { Y2 Sektor } \\
\text { Pertambangan }\end{array}$} & IHSG & .010 & $>0.05$ & Tidak Ada \\
\hline & $\$$ & .280 & $>0.05$ & Tidak Ada \\
\hline \multirow{2}{*}{$\begin{array}{c}\text { Y3 Sektor } \\
\text { Industri Dasar }\end{array}$} & IHSG & .482 & $>0.05$ & Tidak Ada \\
\hline & $\$$ & .625 & $>0.05$ & Tidak Ada \\
\hline \multirow{2}{*}{$\begin{array}{c}\text { Y4 Sektor Aneka } \\
\text { Industri }\end{array}$} & IHSG & .000 & $<0.05$ & $\overline{A d a}$ \\
\hline & $\$$ & .513 & $>0.05$ & Tidak Ada \\
\hline \multirow{2}{*}{$\begin{array}{l}\text { Y5 Sektor } \\
\text { Konsumsi }\end{array}$} & IHSG & .014 & $>0.05$ & Tidak Ada \\
\hline & $\$$ & .968 & $>0.05$ & Tidak Ada \\
\hline \multirow{2}{*}{$\begin{array}{l}\text { Y6 Sektor } \\
\text { Properti }\end{array}$} & IHSG & .000 & $<0.05$ & Ada \\
\hline & $\$$ & .614 & $>0.05$ & Tidak Ada \\
\hline \multirow{2}{*}{$\begin{array}{c}\text { Y7 Sektor } \\
\text { Infrastruktur }\end{array}$} & IHSG & .001 & $<0.05$ & Ada \\
\hline & $\$$ & .926 & $>0.05$ & Tidak Ada \\
\hline \multirow{2}{*}{$\begin{array}{l}\text { Y8 Sektor } \\
\text { Keuangan }\end{array}$} & IHSG & .000 & $<0.05$ & Ada \\
\hline & $\$$ & .782 & $>0.05$ & Tidak Ada \\
\hline \multirow{2}{*}{$\begin{array}{c}\text { Y9 Sektor } \\
\text { Perdagangan }\end{array}$} & IHSG & .000 & $<0.05$ & Ada \\
\hline & $\$$ & 268 & $>0.05$ & Tidak Ada \\
\hline \multirow{2}{*}{$\begin{array}{l}\text { Y10 Sektor } \\
\text { Manufaktur }\end{array}$} & IHSG & .000 & $<0.05$ & Ada \\
\hline & $\$$ & .667 & $>0.05$ & Tidak Ada \\
\hline
\end{tabular}

Sumber : Hasil pengolahan data IBM SPSS 22.

Adapun dasar pengambilan keputusan uji Heteroskedastisitas dalam tabel di atas adalah :

* Jika nilai signifikan lebih besar dari 0.05, kesimpulannya adalah tidak terjadi heteroskedastis. * Jika nilai signifikan lebih kecil dari 0.05, kesimpulannya adalah tidak terjadi heteroskedastis.

Hasil uji heteroskedastisitas berdasarkan tabel 4.I.9 di atas menunjukan model regresi penelitian ini terjadi ketidaksamaan variance dari residual satu pengamatan ke pengamatan lain atau nilainya tidak tetap ( bukan homoskedastisitas), maka dengan demikian model regresi tersebut di kategorikan baik.

\subsubsection{Uji t}

Dalam penelitian ini pengujian hipotesisnya dilakukan dengan dua variabel yaitu Return Saham $\left(X_{1}\right)$ dan Return Saham sektoral $\left(Y_{1} \ldots Y_{10}\right)$, pengujian dilakukan dengan tingkat kepercayaan pada uji ini adalah $95 \%$ atau $a=0,05$. 
t tabel $=\mathbf{t}(a / 2 ; n-k-I)$

$\mathrm{t}$ tabel $=\mathrm{t}(0,05 / 2 ; 60-2-\mathrm{I})=\mathrm{t}(0,025 ; 57)=2.002$

Dengan kriteria pengujian antara lain :

- $\quad$ Ho diterima, jika $t_{\text {hitung }}<t_{\text {tabel }}$ atau $-t_{\text {tabel }}<t_{\text {hitung }}$

- Ho dtolak, jika $t_{\text {hitung }}>t_{\text {tabel }}$ atau $-t_{\text {hitung }}<t_{\text {tabel }}$

\section{I.10 Hasil thitung}

Hasil uji $t_{\text {hitung }}$ yang di dapat dirangkum dalam tabel sebagai berikut :Tabel

\begin{tabular}{|c|c|c|c|c|c|c|c|c|}
\hline \multicolumn{9}{|c|}{ Coefficients $^{2}$} \\
\hline Hipotesa & \multicolumn{2}{|c|}{ Variable } & Sig. & & Nilai & t & Kriteria & $\begin{array}{l}\text { Pengaruh } \\
\text { Sig. }\end{array}$ \\
\hline 1 & \multirow{2}{*}{$\begin{array}{l}\text { Y1 Sektor } \\
\text { Pertanian }\end{array}$} & IHSG & .200 & \multirow{2}{*}{0.05} & \multirow{2}{*}{2.002} & 1.296 & Ho diterima & tidak \\
\hline$\|$ & & $\$$ & .984 & & & .020 & Ho diterima & tidak \\
\hline 1 & \multirow{2}{*}{$\begin{array}{c}\text { Y2 Seltor } \\
\text { Pertambangan }\end{array}$} & IHSG & \multirow{2}{*}{.010} & \multirow{2}{*}{0.05} & \multirow{2}{*}{2.002} & 2.667 & Ho ditolak & tidak \\
\hline$\|$ & & $\$$ & & & & 1.092 & Ho diterima & tidak \\
\hline 1 & \multirow{2}{*}{$\begin{array}{c}\text { Y3 Sektor } \\
\text { Industri Dasar }\end{array}$} & IHSG & \multirow{2}{*}{$\begin{array}{l}.482 \\
.625 \\
\end{array}$} & \multirow{2}{*}{0.05} & \multirow{2}{*}{2.002} & .708 & Ho diterima & tidak \\
\hline$\|$ & & $\$$ & & & & .491 & Ho diterima & tidak \\
\hline 1 & \multirow{2}{*}{$\begin{array}{c}\text { Y4 Seltor Aneka } \\
\text { Industri }\end{array}$} & IHSG & .000 & \multirow{2}{*}{0.05} & \multirow{2}{*}{2.002} & 4.765 & Ho ditolak & ya \\
\hline$\|$ & & $\$$ & .513 & & & -659 & Ho diterima & tidak \\
\hline 1 & \multirow{2}{*}{$\begin{array}{l}\text { Y5 Seltor } \\
\text { Konsumsi }\end{array}$} & IHSG & .004 & \multirow{2}{*}{0.05} & \multirow{2}{*}{2.002} & 2.526 & Ho ditolak & ya \\
\hline$\|$ & & $\$$ & .968 & & & -040 & Ho diterima & tidak \\
\hline 1 & \multirow{2}{*}{$\begin{array}{l}\text { Y6 Sektor } \\
\text { Properti }\end{array}$} & IHSG & .000 & \multirow{2}{*}{0.05} & \multirow{2}{*}{2.002} & 5.850 & Ho ditolak & уа \\
\hline$\|$ & & $\$$ & .614 & & & -.507 & Ho diterima & tidak \\
\hline 1 & \multirow{2}{*}{$\begin{array}{l}\text { Y7 Sektor } \\
\text { Infrastruktur }\end{array}$} & IHSG & .001 & \multirow{2}{*}{0.05} & \multirow{2}{*}{2.002} & 3.566 & Ho ditolak & ya \\
\hline$\|$ & & $\$$ & .926 & & & -093 & Ho diterima & tidak \\
\hline 1 & \multirow{2}{*}{$\begin{array}{l}\text { Y8 Sektor } \\
\text { Keuangan }\end{array}$} & IHSG & .000 & \multirow{2}{*}{0.05} & \multirow{2}{*}{2.002} & 7.305 & Ho ditolak & yа \\
\hline$\|$ & & $\$$ & .782 & & & .278 & Ho diterima & tidak \\
\hline 1 & \multirow{2}{*}{$\begin{array}{l}\text { Y9 Seltor } \\
\text { Perdagangan }\end{array}$} & IHSG & .000 & \multirow{2}{*}{0.05} & 2000 & 5.352 & Ho ditolak & ya \\
\hline$\|$ & & $\$$ & .268 & & 2.002 & 1.119 & Ho diterima & tidak \\
\hline 1 & & IHSG & .000 & 005 & 2002 & 5.135 & Ho ditolak & ya \\
\hline III & & 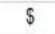 & .667 & 0.00 & & -.432 & Ho diterima & tidak \\
\hline
\end{tabular}

Sumber : Hasil pengolahan data IBM SPSS 22.

Dari hasil perhitungan di atas diperoleh hasil pengujian hipotesi variabel IHSG terhadap return saham sektoral pertambangan $2.667 \mathrm{t}_{\text {hitung }}>2.002 \mathrm{t}_{\text {tabel }}$ maka Ho ditolak dan terdapat pengaruh yang signifikan dan searah antara kedua variabel tsb. Berikut Gambar 7. Distribusi Normal Hubungan IHSG terhadap Saham Pertambangan.

Hasil penerimaan dan penolakan Ho (uji t) Variabel Return IHSG $\left(\mathrm{X}_{1}\right)$ terhadap Return Saham Pertambangan $\left(\mathrm{Y}_{2}\right)$

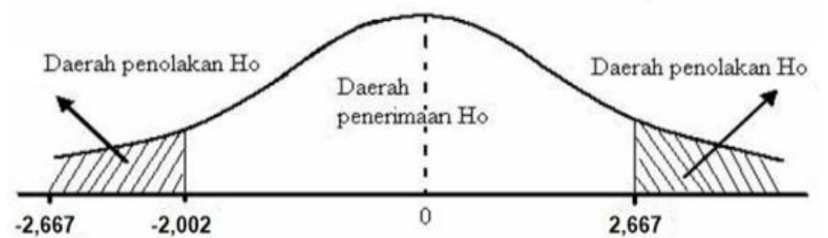

\subsubsection{Uji F}

Pengujian regresi berganda linier secara simultan dilakukan pada penelitian ini dimana apakah ada persamaan regresi berganda antara variabel (XI) Return IHSG dan (X2) Return \$ secara bersama-sama berpengaruh atau tidak terhadap variabel (Y) Return Saham Sektoral.Tingkat kepercayaan pada uji ini adalah $95 \%$ atau $a=0,05$.

$\mathbf{F}$ tabel $=\mathbf{F}(\mathbf{k} ; \mathbf{n}-\mathbf{k}) \mathrm{F}$ tabel $=\mathrm{F}(2 ; 60-2) \mathrm{F}$ tabel $=\mathrm{F}(2$ ;58) $=3.16$

\begin{tabular}{|c|r|r|r|r|r|c|}
\hline \multicolumn{7}{|c|}{ ANOVA } \\
\hline Model & F(hitung) & Sig. & Nilai (a) & $\begin{array}{c}\text { Nilai f } \\
\text { (tabel) }\end{array}$ & Kriteria & $\begin{array}{c}\text { Pengaruh } \\
\text { Sig. }\end{array}$ \\
\hline $\begin{array}{c}\text { Y1 Return Saham } \\
\text { Pertanian }\end{array}$ & .986 & $.379^{9}$ & 0.05 & 3.16 & Ho diterima & Tidak \\
\hline $\begin{array}{c}\text { Y2 Return Saham } \\
\text { Pertambangan }\end{array}$ & 3.556 & $.035^{\circ}$ & 0.05 & 3.16 & Ho ditolak & Tidak \\
\hline $\begin{array}{c}\text { Y3 Return Saham } \\
\text { Industri Dasar }\end{array}$ & .277 & $.759^{9}$ & 0.05 & 3.16 & Ho diterima & Tidak \\
\hline $\begin{array}{c}\text { Y4 Return Saham } \\
\text { Aneka Industri }\end{array}$ & 15.250 & $.000^{\circ}$ & 0.05 & 3.16 & Ho ditolak & Ya \\
\hline $\begin{array}{c}\text { Y5 Return Saham } \\
\text { Konsumsi }\end{array}$ & 3.844 & $.027^{\circ}$ & 0.05 & 3.16 & Ho ditolak & Tidak \\
\hline $\begin{array}{c}\text { Y6 Return Saham } \\
\text { Properti }\end{array}$ & 21.914 & $.000^{\circ}$ & 0.05 & 3.16 & Ho ditolak & Ya \\
\hline $\begin{array}{c}\text { Y7 Return Saham } \\
\text { Infrastruktur }\end{array}$ & 7.726 & $.001^{\circ}$ & 0.05 & 3.16 & Ho ditolak & Ya \\
\hline $\begin{array}{c}\text { Y8 Return Saham } \\
\text { Keuangan }\end{array}$ & 30.817 & $.000^{\circ}$ & 0.05 & 3.16 & Ho ditolak & Ya \\
\hline $\begin{array}{c}\text { Y9 Return Saham } \\
\text { Perdagangan }\end{array}$ & 14.935 & $.000^{\circ}$ & 0.05 & 3.16 & Ho ditolak & Ya \\
\hline $\begin{array}{c}\text { Y10 Return Saham } \\
\text { M anufaktur }\end{array}$ & 16.846 & $.000^{\circ}$ & 0.05 & 3.16 & Ho ditolak & Ya \\
\hline
\end{tabular}

Hasil uji $f_{\text {hitung }}$ yang di dapat dirangkum dalam tabel sebagai berikut: Tabel 4.I.I I sil fhitung

Sumber : Hasil pengolahan data IBM SPSS 22.

Dengan kriteria pengujian antara lain :

- Ho diterima, jika $f_{\text {hitung }}<f_{\text {tabel }}$ atau $-f_{\text {tabel }}<f_{\text {hitung }}$

- Ho dtolak, jika $f_{\text {hitung }}>f_{\text {tabel }}$ atau $-f_{\text {hitung }}<f_{\text {tabel }}$

Setelah dilihat dari tabel nilai statistik $F$ terhadap variabel Y dalam tabel 4.I.I I dinyatakan bahwa :

* Return $\quad$ Saham Sektor Pertanian $\left(\mathrm{Y}_{1}\right): \rightarrow$ tidak ada pengaruh yang signifikan.

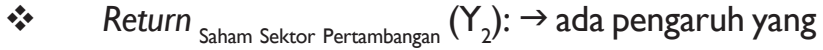
signifikan. 
* Return Saham Sektor IndustriDasar $\left(\mathrm{Y}_{3}\right): \rightarrow$ tidak ada pengaruh yang signifikan.

* Return Saham Sektor Aneka Industri $\left(\mathrm{Y}_{4}\right): \rightarrow$ ada pengaruh yang signifikan.

* Return Saham Sektor Konsumsi $\left(Y_{5}\right): \rightarrow$ ada pengaruh yang signifikan.

* Return Saham Sektor Properti $\left(\mathrm{Y}_{6}\right): \rightarrow$ ada pengaruh yang signifikan.

* Return Saham Sektor Infrastruktur $\left(Y_{7}\right): \rightarrow$ ada pengaruh yang signifikan.

* Return Saham Sektor Keuangan $\left(\mathrm{Y}_{8}\right): \rightarrow$ ada pengaruh yang signifikan.

* Return Saham Sektor Perdagangan $\left(\mathrm{Y}_{9}\right): \rightarrow$ ada pengaruh yang signifikan.

* Return Saham Sektor Manufaktur $\left(\mathrm{Y}_{10}\right): \rightarrow$ ada pengaruh yang signifikan.

\subsubsection{Uji Hipotesis}

Karena pada penelitian ini terdapat dua variabel bebas, maka penelitian ini dilakukan dengan analisis regresi berganda yang bertujuan untuk mengetahui ada atau tidaknya risiko pengaruh dua atau lebih variabel bebas terhadap variabel terikat.

Sedangkan rumusan hipotesis yang akan diuji adalah :

$\mathrm{HI}=$ terdapat risiko return saham IHSG $(X \mathrm{I})$ terhadap return saham sektoral $\left(Y_{1} . . Y_{10}\right)$

$\mathrm{H} 2$ = terdapat risiko return Kurs Dollar

(X2) terhadap return saham sektoral $\left(Y_{1} . . Y_{10}\right)$ H3 = terdapat risiko return IHSG $(X I)$ dan return Kurs Dollar (X2) secara bersama-sama (simultan) terhadap return saham sektoral $\left(Y_{1} . . Y_{10}\right)$

\section{I.I2.I Pembahasan Penelitian}

Setelah melalui tahapan pengujian asumsi klasik (normalitas, autokorelasi, dan heteroskedastisitas) dari variabel uji berupa return saham sektoral, return IHSG dan return kurs dollar, maka didapat persamaan regresi sebagai berikut:

\section{Return Saham Sektoral $=\beta 0+\beta 1 *$ HSG $+\beta 2 *$ Kurs Dollar 2}

Berdasarkan hasil perhitungan diperoleh nilai koefisien determinasi $(\mathrm{R}$ variabel return saham sektor pertanian sebesar $3.33 \%$, pertambangan I I.I \%, industri dasar I \%, aneka industri $34.9 \%$, konsumsi II.9\%, properti $43.5 \%$, infrastruktur $21.3 \%$, perdagangan $34.4 \%$, manufaktur $37.2 \%$ dijelaskan oleh variabel return IHSG dan return Kurs dollar, sedangkan sisanya dijelaskan oleh variabel lain diluar model penelitian.

Hasil perhitungan program SPSS uji ANOVA (analysis of varians), diperoleh nilai Fhitung variable return saham sektoral pertanian 0.99 , pertambangan 3.56 , industri dasar 0.28 , aneka industri 15.25 , konsumsi 3.84, properti 21.91 , infrastruktur 7.73 , keuangan 30.82, perdagangan 14.93, manufaktur 16.85 dengan $\mathrm{df}$ pembilang $=2, \mathrm{df}$ penyebut $=58 \mathrm{dan}$ taraf signifikan á $=0.05$. Ternyata hasil uji rata - rata dari return saham sektoral tersebut menyatakan Fhitung> Ftabel dengan demikian dinyatakan bahwa return IHSG dan return kurs dollar secara serempak berpengaruh dan signifikan terhadap return saham sektoral.

\section{I.I22Analisis Risiko return saham sektoral BEI periode 2012 s.d 2016}

\section{Saham Sektoral Pertanian}

Menghasilkan rata-rata return saham selama 5 tahun $-0.4 \%$ dengan tingkat penyimpangan $7 \%$ artinya risiko reksa dana ini naik $7.1 \%(-0.4 \%+7 \%)$, sementara itu âeta return saham ini I.I 3 lebih besar dari âeta pasar yang sama dengan I artinya tingkat sensitivitas saham tersebut lebih besar daripada sensitivitas pasar sehingga kategori nilai risikonya tinggi.

\section{Saham Sektoral Pertambangan}

Menghasilkan rata-rata return saham selama 5 tahun $-2.2 \%$ dengan tingkat penyimpangan $6.7 \%$ artinya risiko reksa dana ini naik $4.5 \%(-2.2 \%+6.7 \%)$, sementara itu âeta return saham ini I.4I lebih besar dari âeta pasar yang sama dengan I artinya tingkat sensitivitas saham tersebut lebih besar daripada sensitivitas pasar sehingga kategori nilai risikonya tinggi.

\section{Saham Sektoral Industri Dasar \\ Menghasilkan rata-rata return saham selama 5} tahun $-3.2 \%$ dengan tingkat penyimpangan $23.1 \%$ artinya 
risiko reksa dana ini naik $19.9 \%(-3.2 \%+23.1 \%)$, sementara itu âeta return saham ini 1.57 lebih besar dari âeta pasar yang sama dengan I artinya tingkat sensitivitas saham tersebut lebih besar daripada sensitivitas pasar sehingga kategori nilai risikonya tinggi.

\section{Saham Sektoral Aneka Industri}

Menghasilkan rata-rata return saham selama 5 tahun $-0.01 \%$ dengan tingkat penyimpangan $6.4 \%$ artinya risiko reksa dana ini naik $6.4 \%(-0.01 \%+6.4 \%)$, sementara itu âeta return saham ini 1.07 lebih besar dari âeta pasar yang sama dengan I artinya tingkat sensitivitas saham tersebut lebih besar daripada sensitivitas pasar sehingga kategori nilai risikonya tinggi.

\section{Saham Sektoral Konsumsi}

Menghasilkan rata-rata return saham selama 5 tahun $0.82 \%$ dengan tingkat penyimpangan $4.0 \%$ artinya risiko reksa dana ini naik $4.9 \%(0.82 \%+4.0 \%)$, sementara itu âeta return saham ini 0.94 lebih kecil dari âeta pasar yang sama dengan I artinya tingkat sensitivitas saham tersebut lebih kecil daripada sensitivitas pasar sehingga kategori nilai risikonya rendah.

\section{Saham Sektoral Properti}

Menghasilkan rata-rata return saham selama 5 tahun $0.79 \%$ dengan tingkat penyimpangan $7.5 \%$ artinya risiko reksa dana ini naik $8.3 \%(0.79 \%+7.5 \%)$, sementara itu âeta return saham ini 0.94 lebih kecil dari âeta pasar yang sama dengan I artinya tingkat sensitivitas saham tersebut lebih kecil daripada sensitivitas pasar sehingga kategori nilai risikonya rendah.

\section{Saham Sektoral Infrastruktur}

Menghasilkan rata-rata return saham selama 5 tahun $0.24 \%$ dengan tingkat penyimpangan $4.1 \%$ artinya risiko reksa dana ini naik $4.4 \%(0.24 \%+4.1 \%)$, sementara itu âeta return saham ini 1.03 lebih besar dari âeta pasar yang sama dengan I artinya tingkat sensitivitas saham tersebut lebih besar daripada sensitivitas pasar sehingga kategori nilai risikonya tinggi.

\section{Saham Sektoral Keuangan}

Menghasilkan rata-rata return saham selama 5 tahun $0.33 \%$ dengan tingkat penyimpangan $5.8 \%$ artinya risiko reksa dana ini naik $6.1 \%(0.33 \%+5.8 \%)$, sementara itu âeta return saham ini 1.02 lebih besar dari âeta pasar yang sama dengan I artinya tingkat sensitivitas saham tersebut lebih besar daripada sensitivitas pasar sehingga kategori nilai risikonya tinggi.

\section{Saham Sektoral Perdagangan}

Menghasilkan rata-rata return saham selama 5 tahun $0.75 \%$ dengan tingkat penyimpangan $4.7 \%$ artinya risiko reksa dana ini naik $5.4 \%(0.75 \%+4.7 \%)$, sementara itu âeta return saham ini 0.95 lebih kecil dari âeta pasar yang sama dengan I artinya tingkat sensitivitas saham tersebut lebih kecil daripada sensitivitas pasar sehingga kategori nilai risikonya rendah

\section{0. Saham Sektoral Manufaktur}

Menghasilkan rata-rata return saham selama 5 tahun $0.37 \%$ dengan tingkat penyimpangan $4.3 \%$ artinya risiko reksa dana ini naik $4.6 \%(0.37 \%+4.3 \%)$, sementara itu âeta return saham ini I.0 I lebih besar dari âeta pasar yang sama dengan I artinya tingkat sensitivitas saham tersebut lebih besar daripada sensitivitas pasar sehingga kategori nilai risikonya tinggi.

\section{I.123 Analisis Risiko berdasarkan metode Risk Adjusted Return}

Analisis risiko yang digunakan dalam penelitian ini CAPM, dalam hal ini diperlukan data risk free rate atau investasi bebas risiko dalam hal diasumsikan dengan tingkat bunga $\mathrm{BI}$ menjadi acuan dalam menentukan tingkat bunga SBI.

Perhitungan selama 5 tahun dari periode 2012 s.d 2016 ini menghasilkan Risk Free Rate 0.068 atau $6.80 \%$.

Rata-rata return saham menunjukkan tidak mampu menghasilkan rata-rata return melebihi rata-rata investasi bebas risiko (risk free). Hal ini disimpulkan bawah potensi risiko saham-saham sektoral pada periode 2012 s.d 2016 ini tinggi.

\section{I.I24Analisis Risiko dan Return Portofolio (CAPM)}

Model keseimbangan yang digunakan dalam penelitian ini adalah CAPM dengan menggunakan 
volatilitas return saham sektoral BEl periode 2012 s.d 2016 terhadap return pasar $(R m=0.0043)$ sebagai pengukur risiko.

Dari hasil perhitungan CAPM dihasilkan : (I)saham sektoral pertanian sebesar 0.0037 yang besarnya di bawah return pasar $(<R m)$ menunjukan bahwa risiko dan return berhubungan positif dan pengukuran risiko ada dalam kategori rendah ; (2)saham sektoral pertambangan sebesar -0.0218 yang besarnya dibawah return pasar $(<R m)$ menunjukan bahwa risiko dan return berhubungan negatif dan pengukuran risiko ada dalam kategori rendah ; (3)saham sektoral industri dasar sebesar 0.0320 yang besarnya dibawah return pasar $(<\mathrm{Rm})$ menunjukan bahwa risiko dan return berhubungan positif dan pengukuran risiko ada dalam kategori rendah ; (4)saham sektoral industri dasar sebesar $0.000 \mathrm{I}$ yang besarnya dibawah return pasar $(<R m)$ menunjukan bahwa risiko dan return berhubungan positif dan pengukuran risiko ada dalam kategori rendah ; (5)saham sektoral konsumsi sebesar 0.0082 yang besarnya di atas return pasar (>Rm) menunjukan bahwa risiko dan return berhubungan positif dan pengukuran risiko ada dalam kategori tinggi ; (6)saham sektoral properti sebesar 0.0079 yang besarnya di atas return pasar (>Rm) menunjukan bahwa risiko dan return berhubungan positif dan pengukuran risiko ada dalam kategori tinggi ; (7)saham sektoral infrastruktur sebesar 0.0024 yang besarnya di bawah return pasar $(<\mathrm{Rm})$ menunjukan bahwa risiko dan return berhubungan positif dan pengukuran risiko ada dalam kategori rendah ; (8)saham sektoral keuangan sebesar 0.0033 yang besarnya di bawah return pasar $(<R m)$ menunjukan bahwa risiko dan return berhubungan positif dan pengukuran risiko ada dalam kategori rendah ; (9)saham sektoral properti sebesar 0.0075 yang besarnya di atas return pasar $(>\mathrm{Rm})$ menunjukan bahwa risiko dan return berhubungan positif dan pengukuran risiko ada dalam kategori tinggi; (10)saham sektoral manufaktur sebesar 0.0037 yang besarnya di bawah return pasar $(<R m)$ menunjukan bahwa risiko dan return berhubungan positif dan pengukuran risiko ada dalam kategori rendah.

\section{I.I25Analisis Pengaruh Risiko return IHSG terhadap return Saham Sektoral}

Nilai $t_{\text {tabel }}$ dalam penelitian sebesar 2.002 dan hasil dari perhitungan nilai $t_{\text {hitung }}$ return IHSG terhadap : (I)saham sektoral pertanian sebesar $1.296\left(<t_{\text {tabel }}\right)$ dinyatakan bahwa tidak ada pengaruh risiko secara parsial atau Ho diterima ; (2)saham sektoral pertambangan sebesar $2.667\left(>t_{\text {tabel }}\right)$ dinyatakan bahwa ada pengaruh risiko secara parsial atau Ho ditolak ; (3)saham sektoral industri dasar sebesar $0.708\left(<\mathrm{t}_{\text {tabel }}\right)$ dinyatakan bahwa tidak ada pengaruh risiko secara parsial atau Ho diterima ; (4)saham sektoral aneka industri sebesar $4.765\left(>t_{\text {tabel }}\right)$ dinyatakan bahwa ada pengaruh risiko secara parsial atau Ho ditolak ; (5)saham sektoral konsumsi sebesar $2.526\left(>t_{\text {tabee }}\right)$ dinyatakan bahwa ada pengaruh risiko secara parsial atau Ho ditolak ; (6)saham sektoral properti sebesar $5.850\left(>t_{\text {tabee }}\right)$ dinyatakan bahwa ada pengaruh risiko secara parsial atau Ho ditolak ; (7)saham sektoral infrastruktur sebesar $3.566\left(>t_{\text {tabee }}\right)$ dinyatakan bahwa ada pengaruh risiko secara parsial atau Ho ditolak ; (8)saham sektoral keuangan sebesar 7.305 $\left(>t_{\text {tabel }}\right)$ dinyatakan bahwa ada pengaruh risiko secara parsial atau Ho ditolak ; (9)saham sektoral perdagangan sebesar $5.352\left(>t_{\text {tabel }}\right)$ dinyatakan bahwa ada pengaruh risiko secara parsial atau Ho ditolak ; ( 10$)$ saham sektoral manufaktur sebesar $5.135\left(>t_{\text {tabel }}\right)$ dinyatakan bahwa ada pengaruh risiko secara parsial atau Ho ditolak.

\section{I.I 2.6 Analisis Pengaruh Risiko return Kurs Dol- lar terhadap Return Saham Sektoral}

Nilai $t_{\text {tabel }}$ dalam penelitian sebesar 2.002 dan hasil dari perhitungan nilai $t_{\text {hitung }}$ return IHSG terhadap : (I)saham sektoral pertanian sebesar $0.20\left(<t_{\text {tabel }}\right)$ dinyatakan bahwa tidak ada pengaruh risiko secara parsial atau Ho diterima ; (2)saham sektoral pertambangan sebesar $1.092\left(<\mathrm{t}_{\text {tabel }}\right)$ dinyatakan bahwa tidak ada pengaruh risiko secara parsial atau Ho diterima ; (3)saham sektoral industri dasar sebesar 0.49 l $\left(<t_{\text {tabel }}\right)$ dinyatakan bahwa tidak ada pengaruh risiko secara parsial atau Ho diterima ; (4)saham sektoral aneka industri sebesar $-0.659\left(<t_{\text {tabel }}\right)$ dinyatakan bahwa tidak ada pengaruh risiko secara parsial atau Ho diterima ; (5)saham sektoral konsumsi sebesar $-0.040\left(<t_{\text {tabel }}\right)$ 
dinyatakan bahwa tidak ada pengaruh risiko secara parsial atau Ho diterima ; (6)saham sektoral properti sebesar $5.850\left(<\mathrm{t}_{\text {tabel }}\right)$ dinyatakan bahwa tidak ada pengaruh risiko secara parsial atau Ho diterima ; (7)saham sektoral infrastruktur sebesar $-0.057\left(<t_{\text {tabel }}\right)$ dinyatakan bahwa tidak ada pengaruh risiko secara parsial atau Ho diterima ; (8)saham sektoral keuangan sebesar $0.278\left(<\mathrm{t}_{\text {tabel }}\right)$ dinyatakan bahwa tidak ada pengaruh risiko secara parsial atau Ho diterima ; (9)saham sektoral perdagangan sebesar $1.119\left(<t_{\text {tabel }}\right)$ dinyatakan bahwa tidak ada pengaruh risiko secara parsial atau Ho diterima ; ( 10$)$ saham sektoral manufaktur sebesar $-0.432\left(<\mathrm{t}_{\text {tabee }}\right)$ dinyatakan bahwa tidak ada pengaruh risiko secara parsial atau Ho diterima .

\section{KESIMPULAN}

\section{I Kesimpulan}

Dari penelitian yang telah dilakukan maka dapat disimpulkan beberapa hal seperti yang disebutkan di bawah ini :

I. Penelitian secara simultan berdasarkan uji $\mathrm{F}$ statistik dengan menggunakan taraf nyata $5 \%$ diperoleh simpulan bahwa terdapat pengaruh yang signifikan antara Return IHSG dan Return Dollar AS terhadap Return Saham Sektoral. Dimana dengan niai rata-rata $f_{\text {hitung }}$ seluruh return saham sektoral sebesar $11.62 \mathrm{~F}_{\text {hitung }}>\mathrm{F}_{\text {tabel }}$ 3.I6. Angka tersebut mewakili dari saham sektoral pertambangan, aneka industri, konsumsi, properti, infrastruktur, perdagangan, keuangan dan manufaktur. Nilai $F_{\text {hitung }}<F_{\text {tabel }}$ hanya ditemui dari saham sektor pertanian dan industry dasar.

Sehingga disimpulkan bahwa dengan nilai proporsi 0.80 bahwa $\mathrm{HI}$ diterima dan 0.20 bahwa $\mathrm{HI}$ ditolak pada periode 5 tahun dalam penelitian ini, Pengaruh signifikan terbesar return IHSG \& Dollar terbesar dalam penelitian ini terjadi di saham sektoral aneka industri dengan nilai beta I.57.

2. Penelitian secara parsial, berdasarkan uji t dengan menggunakan taraf nyata $5 \%$, diperoleh simpulan bahwa :

a. Terdapat pengaruh yang signifikan dan searah antara IHSG terhadap rata- rata return saham sektoral yang nilai rata-rata thitung-nya sebesar $3.917 t_{\text {hitung }}>t_{\text {tabel }} 2.002$. Angka tersebut mewakili dari saham sektoral pertambangan, aneka industri, konsumsi, properti, infrastruktur, perdagangan, keuangan dan manufaktur. Nilai $t_{\text {hitung }}<t_{\text {tabel }}$ hanya ditemui dari saham sektor pertanian dan industri dasar. Hal ini menunjukan hubungan yang kuat dan menunjukan arah hubungan yang positif yang berarti semakin menguatnya nilai return IHSG makan akan membuat return saham sektoral meningkat, demikian pula sebaliknya.

Sehingga disimpulkan bahwa dengan adanya pengaruh risiko return IHSG dengan return saham sektoral atau dengan nilai proporsi $0.80 \mathrm{HI}$ diterima dan 0.20 bahwa $\mathrm{HI}$ ditolak pada periode 5 tahun dalam penelitian ini.

b. Tidak terdapat pengaruh yang signifikan dan berlawanan arah antara return kurs dollar terhadap rata-rata return saham sektoral dihitung dalam koefisien korelasi nilai rata-rata nya sebesar $37.87 t_{\text {hitung }}<t_{\text {tabel }} 2.002$ yang mewakili dari saham sektoral pertanian, pertambangan, industry dasar, aneka industri, konsumsi, properti, infrastruktur, perdagangan, keuangan dan manufaktur.

Sehingga disimpulkan bahwa tidak ada pengaruh risiko return USD dengan return Saham Sektoral atau $\mathrm{HI}$ ditolak pada periode 5 tahun dalam penelitian ini.

\subsection{Mitigasi Risiko}

Berdasarkan hasil penelitian penulis mencoba untuk memberikan saran-saran sebagai berikut :

I. Bagi investor langkah mitigasi risiko yang dapat diterapkan adalah :

a. Membuat cadangan kerugian dari hasil investasi secara proposional sebelum melakukan transaksi investasi pada sahamsaham yang memiliki risiko yang tinggi.

b. Membuat SOP (Standart Operational Personal), yaitu prosedur yang diterapkan secara pribadi buat investor itu sendiri dengan cara dalam periode atas skala peluang dengan risiko yang tinggi investor itu tidak melakukan trad- 
ing atau menghidari aktivitas jual/beli saham.

c. Melihat arah perekonomian Indonesia, taksir laju pertumbuhan nasional seperti harga minyak bumi, inflasi, pengaruh politik Negara dan kebijakan pemerintah lainnya.

d. Mengetahui aksi korporasi dari para emiten saham itu sendiri, dengan cara menggali informasi dan berita - berita penting yang berasal dari OJK selaku pelidung investor.

2. Bagi Peneliti, melakukan riset atau penelitian secara berkala dan lebih relevan dengan didasari sumber data terkini atau terbaru agar analisa risiko yang dimiliki berlaku riil dan relevan.

\subsection{Implementasi}

\section{Bagi investor}

Bagi investor dan emiten yang tercatat di BEl, hasil dari penelitian ini dapat membantu mereka dalam menentukan apakah akan menjual, membeli, ataukah menahan saham yang mereka miliki berkenaan dengan fluktuasi IHSG dan perubahan kurs dollar terhadap rupiah di BEI. Karena kesalahan dalam menentukan dan menerapkan strategi perdagangan di pasar modal, akan berakibat buruk bagi perusahaan atau investor sehingga dapat mengalami kerugian apabila retun saham IHSG dan pergerakan kurs dollar memang benar-benar berpengaruh terhadap saham saham sektoral.

\section{Bagi Peneliti Lainnya}

Penelitian ini diharapkan dapat memberikan manfaat pengembangan ilmu pengetahuan khususnya dalam bidang manajemen resiko keuangan serta dapat menjadi bahan referensi selanjutnya.

\subsection{Saran}

Berdasarkan hasil penelitian penulis mencoba untuk memberikan saran-saran sebagai berikut :

I. Bagi investor, sebaiknya investor mempertimbangkan faktor return nilai indeks harga saham gabungan dalam berinvestasi saham, karena hasil ini semakin membuktikan pengaruh positif return IHSG terhadap return saham sektoral di pasar modal. Selain itu faktor kurs rupiah terhadap dollar AS juga perludiperhatikan mengingat peningkatan kurs dollar akan mendorong untuk beralih berinvestasi pada pasar uang. Dan sebaliknya investor selain mempertimbangakan faktor-faktor fundamental ekonomi seperti inflasi, regulasi OJK dan fundamental ekonomi lainnya serta memperhatikan faktor- faktor non fundamental ekonomi seperti keamanan, politik dan social. Karena dari penelitian ini dapat disimpulkan bahwa terdapat pengaruh-pengaruh lain yang cukup besar pengaruhnya terhadap indeks saham sektoral.

2. Bagi peneliti lain, disarankan pula memilih periode waktu yang berbeda dalam kondisi yang berbeda serta pada sektor yang berbeda pula, karena dalam kondisi perekonomian yang belum stabil seperti periode penelitaan yang penulis ambil. 
DAFTAR PUSTAKA

Hartono, Jogiyanto, 2013, Teori Portofolio dan Analisis Investasi, Edisi Kedelapan, BPFE, Yogyakarta.

Hanafi, Mamduh M, 2009. Manajemen Risiko (Edisi 2). Yogyakarta: UPP STIM YKPN.

Husnan, Suad, 200I. Dasar dasar teori portfolio dan analisis sekuritas, UPP AMPYKPN,Yogyakarta.

Jurnal Ekonomia, 2013. Pengukuran Risiko Bisnis dan Risiko Pendanaan dalam perusahaan, Volume 9 No. I, STIEYKPNYogyakarta.

Kansil, Christine, 2002, Pokok-Pokok Hukum Pasar Modal, Pustaka Sinar Harapan, Jakarta.

Manurung,Adler Haymans, 2003, Memahami Seluk Beluk Instrumen Investasi, Adler Manurung Press, Jakarta.

Marsis, Adi Setiawan, 2013, Rahasia Terbesar Investasi, Second
Hope, Jakarta

Otoritas Jasa Keuangan, 20I I. Fungsi, tugas dan wewenang OJK. ( h t t p : / / w w w.o j k. go. i d / w e b / fungsi+tugas+wewenang+OJK+60306.htm)

POJK Nomor I8/POJK.03/2016. POJK tentang Penerapan Manajemen Risiko Bagi Bank Umum, Jakarta.

Tandelilin Eduardus, 200I. Analisis investasi dan manajemen portofolio, Edisi pertama, cetakan pertama, BPFE-Yogyakarta.

Website Bank Indonesia ( www.bi.go.id) Website Bursa Efek Indonesia ( www.idx.co.id ) Website Otoritas Jasa Keuangan (www.ojk.go.id)

Website Badan Pengawas Pasar Modal ( www.bapepam.go.id ) Website www.duniainvestasi.com 